\title{
Multiculturalismo canadiense: bueno para comer, bueno para pensar
}

\author{
MARGARITA DEL OLMO \\ Dpto. de Antropología. CSIC. Madrid
}

\section{RESUMEN}

El artículo presenta un análisis del modelo multicultural canadiense, dividido en dos partes: la primera pretende una aproximación general a través de su expresión política y de las críticas que ha suscitado en la literatura académica canadiense contemporánea, en tanto que la segunda se dedica al estudio de un caso concreto, la ciudad de Toronto, con la intención de buscar cuál es la imagen que el multiculturalismo ofrece a través de un análisis del espacio público de la ciudad.

\section{SUMMARY}

This paper deals with the topic of Multiculturalism in Canada. The author has split her arguments in two sections: the first one analyzes the political model and some different academic reactions regarding it, the second one focuses the attention on the city of Toronto and how its public landscape displays multiculturalism.

Palabras clave: Multiculturalismo. Canadá. Toronto. Paisaje urbano. Antropología visual.

Key words: Multiculturalism. Canada. Toronto. Urban Landscape. Visual Anthropology.

\section{INTRODUCCIÓN}

El preámbulo de la Ley Multicultural en Canadá (Canadian Multiculturalism Act 1998) dice textualmente:

El gobierno del Canadá reconoce la diversidad de los canadienses en cuestiones de raza, origen nacional o étnico, color y religión como una característica de la sociedad canadiense y se ha comprometido a desarrollar una política multicultural, designada para conservar e intensificar la herencia multicultural de los canadien-

RDTP, LVI, 2 (2001): 129-166 
ses, y trabajar, al mismo tiempo, para conseguir la igualdad de todos ellos, tanto en la vida económica, como social, cultural y política de Canadá ${ }^{1}$.

El marco general legal, conocido en Canadá como multiculturalismo, fue puesto en vigor por el Primer Ministro Pierre Elliot Trudeau a partir de 1971 (Husani 1990: 13), aunque la ley mencionada es bastante posterior. Ventiseis años después, la escritora canadiense Hazel Palmer (1997:V) afirmaba:

Pertenecer a Canadá se ha convertido en un sentimiento esquivo para algunos de nosotros que hemos vivido aquí parte de nuestras vidas: independientemente del tiempo, ni nosotros ni nuestra familias somos aceptados como canadienses. Resulta frustrante nacer o haber sido criado en un país en el que se le hace sentir constantemente a uno que es un extraño.

Al elegir estas dos citas como introducción he pretendido poner de relieve una contradicción y servirme de ella para presentar la complejidad de la problemática del tema que se pretende abordar: el multiculturalismo canadiense. El objetivo último del trabajo es proporcionar, a través de este caso concreto, un ejemplo comparativo que pueda resultar útil a la hora de analizar fenómenos parecidos en la sociedad española. Me refiero, concretamente, a la problemática derivada de los procesos de inmigración que han tenido lugar en los últimos años en España, en el marco más amplio de la Unión Europea.

El punto de partida de mi argumentación es que el interés del caso canadiense reside en dos razones fundamentales: en primer lugar, se trata de un país con una larga tradición inmigratoria, y, en segundo, porque en los últimos años el multiculturalismo se ha transformado en un emblema político y en una seña de identidad. La ley valora y celebra de forma positiva las diferencias culturales que resultan como consecuencia de ese proceso inmigratorio a larga escala, estableciendo una serie de medidas para que, al menos en teoría, parezcan plausibles.

El análisis que aquí se propone es fruto de un estudio realizado en dos campañas de trabajo en Canadá, durante los veranos de 1999 y 2000, concretamente en la ciudad de Toronto (provincia de Ontario) ${ }^{2}$, y ha sido

\footnotetext{
1 Tanto ésta como el resto de las citas que aparecen en el texto han sido traducidas por la autora.

${ }^{2}$ Parte de este trabajo ha sido financiada por el gobierno canadiense a través de una beca del Faculty Research Program for Canadian Studies, 2000. La autora quiere expresar su agradecimiento al Department of Geography de York University, y al Prof. James Gibson en especial, por la acogida que proporcionó al proyecto en los años 1999 y 2000; así como al Dr. Fernando Monge, al Prof. Helmuth Fuchs, a la Dra.
} 
diseñado teniendo en cuenta tres niveles de análisis distintos. Por un lado, se trataba de observar el multiculturalismo convertido en imagen, empleando para ello una colección de fotografías de la ciudad de Toronto; por el otro, el multiculturalismo reflejado en los discursos, a partir de los relatos de vidas de una serie de personas residentes en Canadá y que deberían reflejar en sus narraciones los cambios percibidos en el país; y, por último, en la literatura académica publicada recientemente en el país, cuyo denominador común sería una reflexión sobre las distintas formas de ser canadiense, en relación con la percepción de la política multicultural.

Voy a organizar la exposición de los resultados en dos partes. La primera estará dedicada a analizar el modelo, tanto en su expresión política, como a través de las reacciones más críticas que ha suscitado su formulación. La segunda trasladará la argumentación al caso concreto de la ciudad de Toronto, con la intención de buscar la expresión del multiculturalismo en la imagen que ofrece el espacio de la ciudad.

\section{El MUlTiCUlTURALISMO COMO MODELO POLÍTICO PARA ARTICULAR LA DIVERSIDAD}

Canadá ha sido uno de los primeros países del mundo en reconocer de manera oficial que la diversidad cultural es la base de su estructura social, y también en elaborar una serie de medidas políticas para tratar no sólo de conservar sino además desarrollar, esa diversidad. A este reconocimiento se le denomina multiculturalismo. Su sistematización y sus propuestas se encuentran recogidas en la Ley Multicultural del Canadá, cuya última redacción data de 1998. El texto completo de la ley consta de seis páginas, estructuradas en epígrafes: Un preámbulo, que inscribe la ley en un contexto político-legal más amplio, un título, con el que será citada y conocida, una interpretación, que define las instituciones políticas y legales que son mencionadas a lo largo del texto, un desarrollo, que resume la filosofía de la ley, una enumeración de las medidas concretas que pone en vigor, y por último, establece la obligación del ministro designado de hacer un informe anual ante las cámaras del Parlamento, así como la de revisar permanentemente el texto de la ley remitiéndolo a las mismas cámaras. Incluye, por último, una enmienda que concierne a los Territorios del Noroeste, al Territorio del Yukón y al gobierno de

Traude Müllauer-Seichter, y a Guillermo Monge, quienes han enriquecido considerablemente el planteamiento, las observaciones, las discusiones y la documentación de este trabajo, y a la Dra. Carmen Ortiz por la cuidadosa corrección y aclaración de algunas ideas. 
Nunavut. Las medidas concretas que propone para el desarrollo de la política multicultural se desarrollan en los puntos siguientes (Canadian Multiculturalism Act 1998: 3):

a) Reconocer y promover el consenso de que el multiculturalismo refleja la diversidad cultural y racial de la sociedad canadiense, lo que implica la libertad de todos sus miembros para proteger, profundizar y compartir su herencia cultural; b) reconocer y promover la idea de que el multiculturalismo es una característica fundamental de la herencia y la identidad canadiense, y que constituye un recurso de valor incalculable a la hora de plantear el futuro de Canadá;

c) promover la participación completa y equitativa de los individuos y las comunidades de todos los orígenes en el proceso de continua evolución y configuración de todos los aspectos de la sociedad canadiense, así como proporcionar la asistencia necesaria para eliminar cualquier barrera que impida esta participación; d) reconocer la existencia de las comunidades cuyos miembros comparten un origen común y su contribución histórica a la sociedad canadiense, así como fomentar su desarrollo;

e) asegurar que todos los individuos reciben igual tratamiento e igual protección ante la ley, respetando y valorando al mismo tiempo su diversidad;

f) promover y proporcionar asistencia a las instituciones sociales, culturales, económicas y políticas de Canadá para que sean respetuosas y capaces, al mismo tiempo, de incluir el caracter multicultural de Canadá;

g) promover el entendimiento y la creatividad que son consecuencia de la interacción entre individuos y comunidades de orígenes diversos;

h) amparar el reconocimiento y la apreciación de las distintas culturas de la sociedad canadiense y procurar que se reflejen y se desarrollen las expresiones de esas culturas;

i) conservar e incrementar el uso de lenguas distintas del francés y el inglés, reforzando, al mismo tiempo, el estatus y el uso de las lenguas oficiales del Canadá; y j) hacer avanzar el multiculturalismo en todo el Canadá en armonía con el compromiso nacional respecto a las lenguas oficiales

Una lectura cuidadosa de la ley, de la que he citado el fragmento que considero más concreto, ofrece poco más que la declaración de unas buenas intenciones. En primer lugar, resulta sorprendente no encontrar en ella una definición de multiculturalismo, más allá de identificarlo con un reflejo de la diversidad cultural y racial del país (punto a), a pesar de que, a partir de la promulgación de la ley, este multiculturalismo (sin definir) deberá ser reconocido como la seña más importante de la identidad canadiense (punto b). Más chocante resulta aún la presunción de que el entendimiento y la creatividad van a ser la lógica consecuencia de la interacción entre individuos y comunidades de orígenes diversos (punto g). El texto no menciona, en ningún momento, problemas, y como no lo hace, tampoco propone medios para canalizarlos, lo que significa que está dificultando la misma posibilidad de solucionarlos. Por último, me 
gustaría llamar la atención sobre un aspecto de rango superior: la relación entre el multiculturalismo y el biculturalismo anglo-francés. La ley parece supeditar el segundo al primero (punto i), aunque, de nuevo, no preve más que la armonía como consecuencia de la convivencia entre ambos modelos (punto $\mathrm{j}$ ).

Además de este marco legal, uno de los primeros objetivos del trabajo fue explorar qué era lo que los informantes entendían, en líneas generales, por multiculturalismo y cuál era su conocimiento concreto de la ley ${ }^{3}$. Ninguna de las personas entrevistadas había leído el texto, con excepción de los que lo conocían por motivos estrictamente profesionales. Tres ejemplos significativos fueron las siguientes respuestas a la pregunta concreta de qué era el multiculturalismo ${ }^{4}$.

¡Cómo si yo supiera lo que es! [...]. Es que no, nunca he leído nada. Yo no sé cuál es la política multiculturalista, aparte de lo que dicen los periódicos [...]. Bueno en el sentido de que no puede haber discriminación... Bueno en ese sentido de cosas de Acción Afirmativa...

Hummm... multiculturalismo es un concepto interesante. Creo que sobre el papel parece, hummm... parece realmente positivo, ¿verdad? Se..., se percibe como si, como si el racismo no existiera en Canadá, o como si no hubiera existido nunca, y como si el racismo fuera una cosa de los Estados Unidos: siempre de los Estados Unidos, pero nada que ver con Canadá. ¡Y la gente se cree eso! Así que tú eliges venir a Canadá pensando que ésta es la verdad, y cuando se sienten heridos, se dan cuenta de que no es verdad en absoluto, que el racismo es rampante, que hay una larga historia de racismo aquí, como en los Estados Unidos, y que el racismo no termina en la frontera.

Bueno, en primer lugar, ¿qué es lo que los inventores de la palabra multiculturalismo entienden? [...] ¿Qué es cultura?, ¿qué es "multin? [...] En realidad es un juego político [...] Cuando se cree que una cultura es ponerse un pantalón de cuero o..., otra clase de pantalón, brincar tres veces y cantar..., o pegar algunos gritos... Si eso es toda la, la definición de cultura, entonces multiculturalismo será que yo permito al otro de poner su pantaloncito, de pegar su grito y brincar a su manera. Entonces yo ..., muestro una extrema, extremada tolerancia frente a otras expresiones culturales. Pero lamentablemente no es eso. Yo [dije] una vez [que] si se aceptaran las pautas de, de los musulmanes: que se corte la lengua a quien dice una mentira, „no tendríamos políticos!; si se corta la mano al que roba, „no

${ }^{3}$ El texto se encuentra disponible, en inglés y en francés, en las oficinas gubernamentales por $4.50 \$$ canadienses (unas 500 ptas. al cambio actual) y es accesible al público a través de la red de bibliotecas.

4 Tanto los discursos que voy a citar a continuación, como los que aparecerán a lo largo del artículo, son fruto de las entrevistas realizadas, en inglés y en español, durante el verano del año 2000 en Toronto, a ciudadanos canadienses de diversos orígenes y adscripciones. 
halbría] bancos! ¿No?, etc., etc. Es decir, esta parte de la cultura no se incluye en el multiculturalismo, que nadie, según s[é] yo, ha hablado de eso: que se van a introducir otros regímenes judiciales. Entonces nos quedamos con esas partes que no [son] cultura [...]. La Caribana ${ }^{5}$ es una linda fiesta en que..., iqué sé yo!, se consiguen muchas cosas y uno se puede divertir, ipero cultura no es! Entonces, ¿de qué puede tratarse la insistencia del Canadá en propagar un concepto que me es difícil de entender?

He elegido estos tres fragmentos porque reflejan, desde tres perspectivas distintas, una reacción muy común al tema del multiculturalismo. Dicha reacción tiene como denominador común una crítica a la ambigüedad.

El primer discurso — quizá el más sencillo- refleja algo muy interesante: desconocimiento. Pero además, el informante relaciona el tema del multiculturalismo con cierta información que recibe a través de la prensa y con la política de Acción Afirmativa, que es una política en vigor en los Estados Unidos ${ }^{6}$.

El segundo discurso es más complejo porque es más explícito. Reclama la apariencia positiva del concepto en el papel, y por lo tanto en la ley, pero argumenta que ello tiene consecuencias negativas, porque proyecta una imagen del país que provoca el equívoco de identificar el racismo, exclusivamente, con los Estados Unidos.

El tercero introduce aún mayor complejidad, relacionando la ambigüedad del concepto con la imprecisión de lo que se entiende por cultura. El informante argumenta que lo que se identifica con la cultura son, generalmente, las manifestaciones más superficiales de la misma, y que ello induce a eludir otras más importantes y mucho más problemáticas, como pueden ser las contradicciones entre las normas de los distintos sistemas judiciales. La crítica de este fragmento se dirige hacia la negligencia de una ley incapaz de plantear siquiera la siguiente cuestión: ¿qué ocurre cuando las normas de esa diversidad tan celebrada son contradictorias? El informante termina su argumentación preguntándose acerca de los intereses que explican la insistencia del Canadá en defender un conceptó que a él le resulta difícil de entender.

Las cuestiones abordadas nos enfrentan de lleno con la complejidad del tema y plantean algunos de los aspectos más importantes. Pero me

\footnotetext{
${ }^{5}$ Con el nombre de Caribana se celebra en Toronto en agosto un carnaval caribeño que consiste en desfiles, fiestas, conciertos, y distintas actividades.

${ }^{6}$ Acción Afirmativa es una política muy polémica en Estados Unidos, cuyo espíritu se podría resumir diciendo que se trata de ejercer una discriminación positiva para tratar de compensar, hasta que sea necesario, las desigualdades que han sido provocadas por el ejercicio histórico de la discriminación racial (o discriminación negativa).
} 
gustaría además introducir algunas otras opiniones, extractadas de la literatura académica canadiense, donde es posible encontrar reflexiones sobre el modelo multicultural, casi siempre en relación con el tema del significado de ser canadiense en un país que ha institucionalizado la política multicultural hace exactamente dos décadas.

\begin{abstract}
La política del multiculturalismo fue establecida por el Primer ministro Trudeau, en 1971 [...], en respuesta a una recomendación del Libro IV del Informe de la Real Comisión de Bilingüismo y Biculturalismo [...]. El multiculturalismo canadiense legitima los derechos de cada uno de los grupos y comunidades "etno-culturales" de mantener sus rasgos distintivos [...]. La preservación de la identidad étnica se convierte en materia de elección [...]. A lo largo de los años, la política multicultural ha sufrido numerosos cambios y evoluciones hasta que fue introducida como el Acta del Multiculturalismo en Canadá en la Cámara de los Comunes en 1988 [...]. A la hora de enfrentarse a las presiones de asimilación, por un lado, y de "etnitización" por el otro, un grupo étnico se encuentra con tres alternativas. Una opción es la amnesia cultural: olvidar sus raíces y su cultura y adoptar las normas del grupo dominante. En el extremo contrario existe la total "etnitización", lo que significa constreñirse completamente a los límites de la cultura y las instituciones propias. La tercera opción consiste en crear un balance entre ambas reteniendo la parte más significativa de su herencia cultural y, al mismo tiempo, equilibrarla con las experiencias y las necesidades de la realidad social canadiense (Husani 1990:13)
\end{abstract}

La autora identifica la política multicultural con una "tercera vía" entre la asimilación a la sociedad mayoritaria y lo que ella denomina "etnitización", que supondría un proceso de "ghettización" voluntaria. La cuestión radica, efectivamente, en si el modelo multicultural hace posible la existencia de esa tercera vía. Zora Husani reclama que la política canadiense no sólo la hace posible, sino que además capacita al individuo para elegir su estilo de vida. Más adelante veremos opiniones mucho más críticas. Sin embargo, en este momento me interesa abordar otra cuestión suscitada al principio de la cita: la afirmación de que la política multicultural fue establecida en respuesta a la cuestión del bilingüísmo y biculturalismo anglo-francés.

Canadá es un Dominio heredero directamente de una colonia británica (la reina de Canadá es de hecho hoy en día la misma reina que la de Gran Bretaña), cuyo origen es muy complejo. El territorio, originalmente poblado por grupos indígenas, fue colonizado primero por los franceses, quienes cedieron posteriormente su soberanía a la corona británica. Gran Bretaña se encontró así gobernando a unos súbditos que hablaban francés, practicaban la religión católica y se regían por las normas del derecho romano. Después de la Guerra de Independencia de los Estados Unidos, Gran Bretaña aprovechó su soberanía en Canadá para asentar a los partidarios de la causa inglesa que habían perdido esta guerra al sur 
de lo que era el Canadá francés. Este es el origen de las dos tradiciones, francesa y anglosajona, en la colonización del territorio. El gobierno de la colonia reconoció a los canadienses de origen francés un estatus especial desde el principio, y el desarrollo de su historia tiene mucho que ver con las tensiones entre las dos provincias. Todo ello cristalizó, después de la independencia, en el reconocimiento de un estatus bicultural para el país y de dos lenguas oficiales, el inglés y el francés, en todo el territorio. Esta política bicultural, por razones diversas y complejas, no resultó absolutamente satisfactoria para el Canadá francés, que consiguió recientemente instaurar en el ámbito de la provincia de Quebec el francés como único idioma oficial, a pesar de que el bilingüismo seguía estando en vigor en el resto del país. Aun así, una parte importante de los habitantes de Quebec continúan reclamando la independencia total y en los últimos años se han celebrado varios plebiscitos que han perdido la causa por un escaso margen.

Cuando Zora Husani, y otros autores que vamos a ver más adelante, reclaman que la política multicultural es una respuesta a la tensión que representaba el biculturalismo, se refieren a este proceso. Canadá ha sustituido el biculturalismo por el multiculturalismo, aunque, como queda claro en los puntos i y j de la ley (citada más arriba), se propone un crecimiento del segundo, sobre la base del respeto hacia el primero. En este, como en otros puntos, la ley es ambigua y no aclara, en ningún momento, cómo resolver las contradicciones que se puedan derivar de la convivencia entre los dos modelos.

Otro autor canadiense, Zuhair Kashmeri (1991) con argumentos parecidos, sin embargo, refleja una posición mucho más crítica:

El multiculturalismo se convirtió en política oficial en Canadá como una parte de la respuesta del gobierno de Trudeau al desafío de Quebec. La política de Trudeau fue convertir las demandas de soberanía del Quebec en bilingüismo y multiculturalismo para todo el Canadá. El multiculturalismo supone un paso adelante con respecto al modelo americano del "melting pot", donde los recién llegados se deben diluir (lo que, desde cualquier perspectiva, supone ejercer un considerable imperialismo cultural). Canadá decidió mantener a los inmigrantes y sus culturas. [...] Cuando Brian Mulroney ${ }^{7}$ y los «tories" asumieron el poder en Septiembre de 1984 [...] decidieron llevar el multiculturalismo más allá y no sólo promulgaron el Acta del Multiculturalismo en Canadá, sino que crearon un ministerio específico al efecto. [...] El aspecto más curioso del Acta Multicultural es que no define el multiculturalismo, simplemente idolatra los ideales de Canadá como un mosaico, verbalizados en los discursos de los Primeros Ministros [...]. Pero es

\footnotetext{
${ }^{7}$ El actual Primer Ministro.
} 
también una legislación que dejó de tener efecto ante un conflicto de las características de la Guerra del Golfo. En ese momento la política exterior del Canadá tomó preeminencia sobre los derechos de las minorías étnicas (Ibid: 126-127).

En su libro, Kashmeri, analiza la actuación del gobierno canadiense con respecto a sus ciudadanos de origen árabo-musulmán ante la Guerra del Golfo, cuando algunas libertades fundamentales de estos individuos fueron suspendidas, por el mero hecho de su origen, de una manera comparable (exceptuando el internamiento en campos de concentración y la enajenación de las propiedades) a la actuación del gobierno de los Estados Unidos con respecto a sus ciudadanos de origen japonés durante la Segunda Guerra Mundial, cuando fueron considerados personas peligrosas, o potencialmente peligrosas, para la seguridad del país en virtud de su origen. El autor concluye argumentando que Canadá suspendió de hecho, y sin previa advertencia, su política multicultural en favor de su política exterior y su intervención como aliado de los Estados Unidos en la reciente Guerra del Golfo. Esta argumentación conduce al autor a plantear críticamente la eficacia del modelo y a reducirla a una idolatría de los ideales de mosaico en los discursos de los Primeros Ministros". Desde esta perspectiva, su utilidad quedaría reducida a una mera verbalización de deseos, fáciles de olvidar cuando entran en conflicto con otros intereses. Es en este contexto en el que el autor reclama que la política multicultural fue concebida con la intención de resolver la tensión anglocanadiense, diluyéndola en un contexto más amplio en el que intervenían las particularidades de las culturas de origen de la inmigración, lo que además proporcionaría a Canadá una seña de identidad con respecto a los Estados Unidos, ofreciendo una alternativa más atractiva al ya caduco modelo del melting pot en ese país.

Posteriores análisis de la relación entre el multiculturalismo y la tensión anglo-francesa en el Canadá, esta vez realizados en Europa, extraen una conclusión muy interesante:

El multiculturalismo canadiense es una respuesta específica al problema del biculturalismo anglo-francés. Es posible que haya ayudado a los inmigrantes a integrarse mejor, pero ha agravado el problema original del Canadá: el separatismo francés. [...] Si existe una 'lección' para Europa, en este sentido, debería ser la de no tratar de diluir conflictos territoriales específicos, basados en conflictos de minorías, empleando para ello políticas multiculturales generales, sino, al contrario, tratar cada conflicto en sus propios términos (Joppke y Lukes 1999: 17).

Creo que ésta es una de las conclusiones más interesantes del análisis del modelo en relación con Europa, y que es especialmente pertinente para el caso español (un Estado, al fin y al cabo, construido y recons- 
truido sobre la base de distintas tensiones nacionales y modos de reinterpretar el pasado: Pérez Garzón y otros 2000), aunque nada más sea como advertencia para no cometer los mismos errores. En España no han existido hasta el momento, al menos que yo sepa, intentos serios de tratar la cuestión de la diversidad de las identidades tradicionales españolas en conexión con la diversidad aportada por los inmigrantes extranjeros, aunque sí se ha utilizado el ejemplo canadiense como modelo en otro sentido: para comparar el caso quebecois con el catalán. Espero que la reclamación que hace el presente artículo de que el multiculturalismo canadiense es un modelo "bueno para pensar" sea, en este sentido, un argumento a favor de dejar las cosas como están, en este terreno, y en todo caso para seguir el consejo de los autores mencionados cuando afirman que cada conflicto debe ser tratado en sus propios términos.

Otro problema que se aprecia en los análisis del modelo es el tema de los derechos de las comunidades y su relación con los derechos de los individuos. Aunque en este sentido la ley defiende a los últimos a expensas de los primeros (punto e), establece, a la vez, una reivindicación poco clara de los derechos comunitarios, cuando reclama "Promover una participación completa de los individuos $y$ las comunidades" (puntos c y g), y por supuesto vuelve a eludir el tema de qué ocurre cuando los intereses de un individuo entran en conflicto con los de $s u$ comunidad. Este punto resulta especialmente significativo en relación, por ejemplo, con temas como el papel tradicional de las mujeres en algunas comunidades, que es contradictorio con el que les asigna la sociedad canadiense mayoritaria. La autora Ayelet Shachar (1999: 89) lo expresa en estos términos:

La nueva interpretación multicultural de la ciudadanía subraya la interacción entre tres componentes: los individuos, los grupos y el estado, en vez de los dos elementos tradicionales, que se expresaban a través de la dicotomía estado-individuo. Esta filosofía se aparta del ideal de la "ceguera hacia el color" reivindicando que los grupos merecen derechos diferentes; lo que significa que, desde esta perspectiva, los ciudadanos se convierten en individuos que a su vez son parte de las comunidades, y por lo tanto, sus derechos son simultáneamente iguales a todos los demás como individuos y diferentes como miembros de grupos.

Y más adelante afirma:

En determinadas situaciones, el multiculturalismo supone una amenaza a los derechos del ciudadano, por lo menos para muchas mujeres, que están atrapadas en la intersección de múltiples afiliaciones [...]. La afirmación multicultural de la identidad, derivada de una afiliación religiosa, racial, étnica o tribal, comete el error de organizar la multiplicidad de las distintas afiliaciones, y mucho más importan- 
te, elude la posibilidad de apreciar la vulnerabilidad particular de determinadas clases de individuos, tales como las mujeres, quienes pueden sufrir una condición de subordinación tradicional en el contexto de sus propias culturas (Ibid.: 91).

La autora finaliza su argumentación con una propuesta:

La cuestión más importante del modelo de la ciudadanía multicultural no es $s i$ el estado debe o no intervenir en los grupos comunitarios. Ya que su intervención es un hecho inevitable. La cuestión central radica en cómo debe intervenir el estado: cuándo, de parte de quién y sobre qué criterios. Para responder estas cuestiones tan complejas es necesario desarrollar un modelo de ciudadanía multicultural "modificado", que sea sensible no sólo a la diversidad que existe entre los distintos grupos, sino que además tenga en cuenta los intereses de los líderes de los grupos y los de "las voces de dentro", especialmente las que pertenezcan a individuos que son sujeto de maltrato por parte de las tradiciones del grupo (Ibid.: 100).

Jeff Spinner Halev (1999: 84) amplía esta misma argumentación, abordando el tema de las clases sociales en el contexto del multiculturalismo, y aboga por lo que denomina un "Multiculturalismo inclusivo":

Un multiculturalismo inclusivo es un derecho de luchar por incluir a los que han sido excluidos a causa de unas prácticas culturales diferentes. Algunas veces este hecho es suficiente para reclamar la ciudadanía. Sin embargo, con mucha más frecuencia el camino hacia la inclusión en el grupo y la ciudadanía tiene mucho más que ver con barreras de riqueza y de poder. Aceptar el multiculturalismo supone permitir a un mayor número de gente entrar dentro del recinto amurallado, pero los pobres seguirán quedándose fuera. Por eso es necesario defender un tipo distinto de ciudadanía, más inclusivo, en el que cada uno pueda erigir muros en torno a sus vecinos y amigos, pero asegurándose de que los muros conectan hacia el exterior a través de muchas puertas.

Por su parte, Rainer Bauböck (1999: 151) hace una defensa de la diversidad en las sociedades contemporáneas argumentando de esta forma:

Creo realmente que la movilidad y la migración en las sociedades contemporáneas enfrenta cada día a más y más personas con el dilema de la elección de su pertenencia cultural, y también que la posibilidad de combinar distintas afiliaciones, en vez de tener que elegir una a expensas de las demás, es uno de los elementos más deseables de la diversidad entendida desde una perspectiva liberal. [...] La diversidad es [...] un bien público que se produce gracias a las aportaciones de todos y que, igualmente, debe ser disfrutada por todos.

En mi opinión, cualquier crítico del modelo multicultural aceptaría esta posición, el problema radica en las posibilidades sociales que ofrece al respecto. Así la autora canadiense Mirna Kostash (2000: 177) reflexiona: 
La sociedad canadiense tiene que preguntarse todavía si el multiculturalismo oficial no es más que una máscara de reafirmación, detrás de la cual sigue escondiéndose el poderoso dilema de decidir qué es la cultura canadiense y quién pertenece a ella. Ambas cuestiones tienen raíces profundas en nuestro pasado, pero son, a la vez, cuestiones decisivas para nuestro futuro.

Este tipo de argumentaciones nos devuelve al punto de partida, cuando otra autora canadiense, Hazelle Palmer, escribía que, como persona de $\operatorname{color}^{8}$, le resultaba difícil ser aceptada en Canadá:

¿De dónde eres realmente? ${ }^{9} \mathrm{O}$ ¿đde dónde son tus padres? son preguntas cargadas de significado a las cuales se enfrentan diariamente las personas de color nacidas en Canadá o que han crecido aquí. En realidad sugieren que nosotros no parecemos canadienses. Quizá también sugieren el tema de que la persona que hace la pregunta, probablemente sin darse cuenta, necesita colocarnos en un país que piensa que es más representativo de nuestro aspecto: si somos negros, probablemente tenemos que ser de Jamaica, si parecemos asiáticos, significa que somos de China o de Hong Kong. La necesidad de probar nuestros orígenes nos mantiene extranjeros para siempre, inmigrantes para siempre. Además las preguntas tienen una naturaleza racista, ya que asumen que por el hecho de no ser blancos no podemos ser canadienses. Su lógica está basada en presunciones colonialistas y racistas sobre cómo es Canadá y qué significa ser canadiense (Palmer 1997: V-VI).

La autora reacciona de forma muy crítica hacia la política multicultural:

Incluso el multiculturalismo, que hace profesión de mantener y celebrar la miríada de culturas de Canadá, continúa considerando a la gente de color como Otro. No nos permite contribuir a una redefinición de lo canadiense, al contrario, está ayudando a mantener el statu quo que funciona para mantenernos al margen (Ibid.: 9).

Aquí coincide con la opinión que ofreció un informante a lo largo de una entrevista, de la que voy a citar el siguiente fragmento:

¿Sabes?, la gente me dice continuamente: yo vine a Canadá porque pensé que esto no me iba a ocurrir ly se refieren a la denuncias de comportamientos racistas], por eso es por lo que no fui a los Estados Unidos, o a Inglaterra. No entiendo por qué tiene que ocurrir así. De hecho hay mucha gente que no ha sido capaz de recuperarse.

En este punto creo que cabe preguntarse ¿cuál es la diferencia que ofrece Canadá con respecto a otros países que no tienen un modelo multicultural? Del análisis del multiculturalismo como modelo político para

\footnotetext{
${ }^{8}$ La autora emplea la expresión "de color" no como un eufemismo, sino para incluir tanto negros como personas de aspecto oriental, latino, indio, etc.

${ }^{9}$ De hecho esta pregunta es utilizada como título de su libro (Palmer 1997).
} 
articular la diversidad se desprenden una serie de cuestiones críticas, que voy a tener en cuenta más adelante, a la hora de analizar la expresión de las diferencias étnicas en el caso concreto de la ciudad de Toronto. Entre ellas me parecen especialmente relevantes las siguientes:

La ley multicultural es una ley ambigua que celebra la diversidad, pero que no reconoce la posibilidad de que esa diversidad provoque ningún tipo de contradicciones en la creación de una estructura social, de acuerdo con el marco político que propone. Los problemas, sin embargo, no desaparecen por el mero hecho de ser eludidos, más bien ocurre lo contrario: se esconden debajo de una cáscara que celebra la diversidad y sorprenden cuando uno se enfrenta a ellos en la vida diaria, dificultando la posibilidad de atribuirlos al contexto social, y obligando al individuo que los sufre a afrontarlos únicamente como una cuestión personal.

El modelo propaga una idea de un Canadá diverso que sólo parece tener lugar a la hora de comer, celebrar fiestas o vestirse siguiendo tradiciones distintas. Sin embargo, esta imagen es superficial y deja, de nuevo, sin resolver problemas graves en relación con el origen bicultural del Canadá (si es o no prioritario sobre el multiculturalismo), en relación con los derechos del ciudadano (si son comunitarios o individuales), con la política exterior del Canadá (si el multiculturalismo es una ley de rango superior o no a la política exterior del país), etc. El multiculturalismo se reduce, al fin y al cabo, a la posibilidad de experimentar con nuevas comidas, bailar al son de distintas y exóticas músicas o colorear el paisaje urbano con estilos diferentes de vestido, y al mismo tiempo permite seguir practicando un estilo de vida propio en la medida en que no entre en conflicto con las normas sociales tradicionales de la mayoría. Un multiculturalismo de estas características no implica el trabajo de negociación social continuo que requiere el convivir entre normas contradictorias. Si cada vez que aparece un conflicto entre intereses jurídicos, por ejemplo, se recurre, en última instancia, a una ley impuesta con anterioridad al modelo multicultural y no consensuada a raíz de éste, el multiculturalismo se reduce a una mascarada, a un carnaval urbano en el que la diversidad se articula solamente a través de un atractivo desfile colorista, más allá del cual los problemas derivados de la convivencia con la diversidad permanecen sin resolver.

A pesar de todo ello, es necesario tener en cuenta un aspecto muy importante del modelo multicultural que, hasta este momento, he dejado deliberadamente al margen. Me refiero a su efecto como propaganda. En un mundo como el actual, caracterizado por la enorme disponibilidad del individuo de imaginarse viviendo estilos de vida distintos (Appadurai 1995 y 1998), gracias, por un lado, a la accesibilidad y la rapidez de los medios de transporte que permiten desplazarse por el mundo a una escala 
sin precedentes, y, por el otro, a los medios de comunicación de masas que alcanzan audiencias remotas y consiguen hacer próximas y cotidianas unas imágenes que pertenecen al otro extremo del globo, el modelo multicultural como propaganda tiene unos efectos también sin precedentes a la hora de atraer inmigración. De manera que, y en este punto coincido plenamente con Sharon Zukin (1995: viii):

Aceptar la diversidad implica compartir el espacio público (las calles, los autobuses, los parques y las escuelas) con gente que vive, de forma visible, y quizá también vehemente, estilos de vida que uno mismo desaprueba.

Por este motivo me gustaría trasladar ahora el análisis del multiculturalismo canadiense y su capacidad para articular la diversidad a un escenario concreto: a la imagen pública de las diferencias en el espacio visible de la ciudad de Toronto.

\section{LA CIUDAD DE TORONTO COMO ESCAPARATE DEL MULTICULTURALISMO}

Toronto es la capital de la provincia de Ontario, la ciudad más poblada del Canadá, y también donde reside el mayor número de inmigrantes, tanto en términos relativos como absolutos.

Toronto recibe actualmente dos tercios de las personas que llegan a Canadá ${ }^{10}$.

La vida diaria de su población tiene lugar en un espacio articulado en una retícula de calles, ordenadas en torno a dos ejes que discurren uno de norte a sur (la calle Yongue) y otro de este a oeste (la calle Bloor). Estos ejes se cruzan en el número 0 para ambas calles, y a partir de ahí los números crecen en sentido este, oeste, norte y sur. En torno a este centro cardinal, y desplazándose hacia el sur, se constituye lo que se conoce como el Downtown Toronto. El límite sur del Downtown lo establece la orilla norte del lago Ontario, donde las calles abandonan su estructura reticular para adaptarse a la geografía. Hacia el norte, el este y el oeste se han ido formando municipios que, desde mediados del siglo $\mathrm{xx}$, se gobiernan conjuntamente a través de un Consejo, constituyendo la Corporation of Metropolitan Toronto, que ha sufrido diversas reorganizaciones a lo largo de su historia.

La retícula de calles está interrumpida por los ravines, que son espacios naturales respetados como caminos de deshielo hacia el lago, y apro-

${ }^{10}$ Entrevista realizada en agosto del año 2000. 
piados por los habitantes para la vida urbana en forma de espacios verdes, en los cuales no está permitido ningún tipo de construcción.

Aunque el medio de transporte más corriente es el coche, la ciudad dispone de una considerable red de transportes públicos, organizados en torno a dos líneas de metro (que discurren a lo largo de los dos ejes de la ciudad y que se cruzan en el centro), una red de tranvías, y otra mayor de autobuses que parten radialmente de centros de distribución, conectados con las estaciones de metro.

El horizonte de la ciudad está constituido por una línea continua de escasa altura (dos o tres pisos es lo más corriente), interrumpida, de manera aislada, por edificios más altos y, de forma mucho más evidente, por el grupo de rascacielos que constituyen la zona financiera del Downtown y están presididos por la $C N$ Tower, un edificio destinado a comunicaciones y observatorio que es la construcción más emblemática de la ciudad.

Parte del subsuelo en el Downtown cuenta con un considerable conjunto de calles y comercios que discurre a lo largo de kilómetros, se conecta con las paradas de metro centrales, y protege a la población que lo transita de los rigores del invierno y del efecto sofocante de la humedad durante el verano.

Todos estos elementos conforman las coordenadas principales en torno a las cuales se crea y se negocia constantemente el significado del espacio público. En este proceso se reflejan las ideas de sus habitantes sobre el multiculturalismo y el poder del que dispone cada cual para imponer y mostrar (o esconder) su propia imagen en la vida en la ciudad.

Los idiomas oficiales son el inglés y el francés, pero la riqueza lingüística modela el espacio público de una forma muy característica, puesto que la presencia de distintos idiomas y alfabetos, y tradiciones musicales es constante en la vida diaria. No sólo el sonido y la imagen reflejan una gran diversidad, ésta también se puede apreciar a través de otros sentidos, tales como el olfato y el gusto: la variedad de los mercados, cocinas y restaurantes es impresionante, y está relacionada (aunque no directamente) con los lugares de origen de los habitantes ${ }^{11}$.

${ }^{11} \mathrm{La}$ imagen que ofrecen estos establecimientos también se adapta a la que los clientes tienen sobre su nacionalidad de origen. Por ejemplo en el barrio griego una representación del Partenón está presente en restaurantes, tiendas de comida, bancos o agencias inmobiliarias, porque es algo que evoca fácilmente en los clientes la idea de Grecia. De la misma forma, un restaurante italiano tiende a contratar camareros italianos, independientemente de que el dueño sea de otra nacionalidad, porque el público parece suponer que la comida que sirven ellos es más genuinamente italiana. Cuando el multiculturalismo se convierte en una forma de hacer negocio, el origen 
Robert J. Kasher (1997) es autor de un libro que tiene la intención, como declara el subtítulo, de ser "Una guía completa de las muchas caras y culturas de Toronto". El autor se refiere a quince "Torontos" distintos: afrocaribeño, árabe y de Oriente Medio, de los Balcanes, inglés e irlandés, chino, francés, alemán, griego, indio y del sur de Asia, italiano, japonés y del sureste asiático, judío, latino, ruso, de Europa del este y, por último de Europa central y occidental. A cada uno de estos "Torontos" le dedica un capítulo, en el que habla de las nacionalidades de origen de sus habitantes, sus religiones, los distintos tipos de organizaciones, las fiestas y las celebraciones, los restaurantes, cafés y clubs nocturnos, los recursos alimenticios, las tiendas y los medios de comunicación. Y los distribuye en la retícula de calles que organizan el espacio de la ciudad. El autor afirma de forma general en la introducción (1997: IX):

\begin{abstract}
Toronto ejerce muchos tipos de atracción para los visitantes, como la ciudad moderna, limpia, vibrante y atractiva que es, pero su mayor interés radica en la diversidad de su gente. Toronto es la ciudad más multicultural del mundo. Su población, cercana a los cuatro millones de habitantes, contiene alrededor de setenta y cinco culturas diferentes, con al menos mil miembros cada una. Su mayor grupo étnico representa tan solo un poco más del $20 \%$ de su población. Más de una docena de culturas cuentan con más de 100.000 personas en el área metropolitana. Toronto, que fue conocida durante muchos años como una de las ciudades de mentalidad más estrecha y provinciana del Imperio Británico, se ha convertido en los últimos treinta años en la ciudad con mayor diversidad étnica y cultural del mundo.
\end{abstract}

Este tipo de opiniones sobre la ciudad son muy comunes, coinciden perfectamente con la imagen oficial que se difunde sobre ella y que se expresa de una forma muy significativa en el calendario de actividades festivas promovidas desde el Ayuntamiento ${ }^{12}$. Ahora bien, ¿qué relación existe entre esta idea de diversidad que se atribuye a la ciudad de Toronto y el modelo multicultural?

Uno de los objetivos propuestos en el diseño del trabajo, como dije en la introducción, era analizar el multiculturalismo reflejado en las imágenes de Toronto. Con este objetivo he realizado más de 400 diapositivas.

geográfico y cultural de la imagen que se pretende vender, debe ser reconocible por el público. De esta forma, los símbolos que identifican la diversidad se esquematizan de tal forma que acaban resultando pobres. En cada uno de los barrios "étnicos" que he visitado, el color de la bandera de origen de la comunidad identifica al barrio en sí mismo.

${ }^{12}$ La impresionante lista de fiestas puede consultarse en el libro mencionado de Kasher (1997). 
Sin embargo, no he sido capaz de reflejar en ellas mi impresión de la diversidad en las calles de la ciudad: desde este punto de vista el reportaje fotográfico ha resultado improductivo. Pero uno de los frutos del trabajo realizado ha sido, precisamente, preguntarme acerca de las razones de este fracaso.

El marco de una fotografía es muy limitado, y por lo tanto lo es también la imagen que ofrece, porque la singulariza y la extrae de su contexto. Mis imágenes no son nada más que trozos desprovistos de su relación con otros trozos, y, además, de su contexto. La primera conclusión de mi fracaso fue entender, por lo tanto, que si el multiculturalismo está en algún lugar debe buscarse en la relación y en el contexto. Sin embargo, no se trata únicamente de una limitación impuesta por el medio empleado, es también una consecuencia de la naturaleza del propio tejido social producido por el multiculturalismo. Un poeta cingalo-canadiense llamado Krisantha Sri Bhaggiyadatta en un poema titulado "La única minoría es la burguesía", expresa, de manera sarcástica, pero mucho mejor de lo que a mí se me ha ocurrido, esta misma idea:

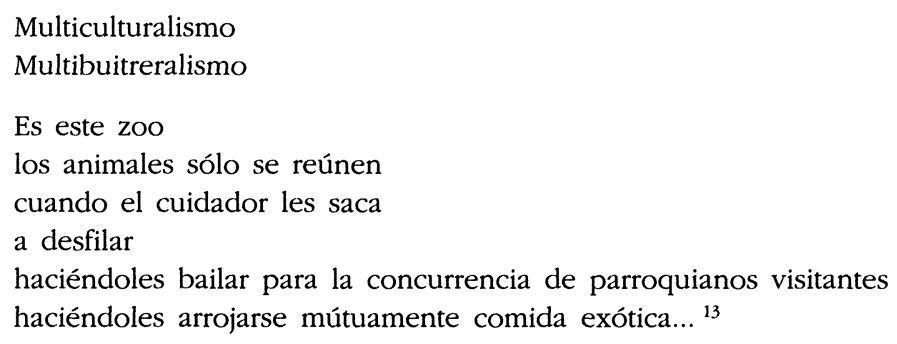

Si esta crítica es acertada, aunque haya sido expresada a través de una metáfora que subraya su crudeza, las imágenes captadas coinciden con la argumentación de que la diversidad que se percibe es una imagen de carnaval, promovida para popularizar únicamente bailes, músicas y comidas exóticas. Y que la diversidad se introduce en la vida cotidiana

${ }^{13}$ El poema original, que yo he extraído de Sugunasiri (1999:16), dice así:

Multiculturalism

Multivulturalism

In this zoo

the animals only come together

when the keeper brings them out

in a caravan

to dance for the visiting citizenry

to throw exotic food at each other... 
precisamente a través de esa imagen de exotismo, entrando así a formar parte del tejido social. Desde esta perspectiva, los quince "Torontos" étnicos identificados por Kasher no serían más que lugares perfectamente delimitados como escenarios, donde los habitantes de la ciudad van a "comer griego", a comprar especias chinas o frutas caribeñas, a cenar comida italiana, a adquirir un sari indio para proporcionar un toque original a una fiesta o a bailar sambas brasileñas.

En este punto del desarrollo del trabajo, no creo que semejante conclusión resulte sorprendente, puesto que coincide con ideas semejantes sugeridas por el análisis de los discursos, la ley y reflexiones académicas acerca de la identidad canadiense en relación con el multiculturalismo. Sin embargo, he de reconocer que esta reflexión ha seguido un camino mucho más tortuoso, partiendo de las imágenes. Una idea como ésta resultaba absolutamente contraria a mi impresión sobre el terreno, donde llegué a sentirme completamente abrumada por la diversidad. A pesar de ello, después del análisis de los distintos materiales, he llegado a la conclusión de que mis observaciones eran superficiales: lo que veía era el escenario, detrás del cual se negociaba la vida cotidiana. Cuando organicé mis visitas a los distintos barrios de Toronto (entre los que incluí, para sorpresa de muchos de mis interlocutores, el barrio "étnico" inglés ${ }^{14}$ ) a partir de una guía "étnica" de Toronto, no hacía más que reconocer lo que estaba buscando. Las fotografías, sin embargo, muestran un panorama diferente, en el que las señas con las que se pretende marcar la etnicidad son meramente unos detalles en la escenografía. Por poner sólo un ejemplo concreto: creí ver un barrio griego plagado de carteles, restaurantes, tiendas y colores griegos. En las fotos del barrio griego estas señales aparecen sólo de forma muy esporádica (véase la fig. 1 en la que la "etnicidad griega" queda representada únicamente por el nombre de la calle en alfabeto griego y por los colores azul y blanco del cartel, que son una referencia explícita a los colores de la bandera de Grecia).

He sufrido este mismo proceso de transformación en cada uno de los distintos "Torontos" que he visitado, de manera todos ellos se han ido transformando en escenarios étnicos. A pesar de todo, voy a emplear las fotos para tratar de hacer otro tipo de análisis. Utilizaré algunos ejemplos de mi colección de fotografías para preguntarme acerca de la manera en que se emplea el espacio público, cómo se transforma y se negocia, y qué relación tiene esta apropiación del espacio con el modelo de la multiculturalidad. Se trata, en definitiva de argumentar cómo se estructura

14 Nadie se refiere al barrio inglés con el apelativo de "étnico", de manera que se usa la etiqueta "étnica" como una forma de marcar a los que no pertenecen a las élites de poder. 


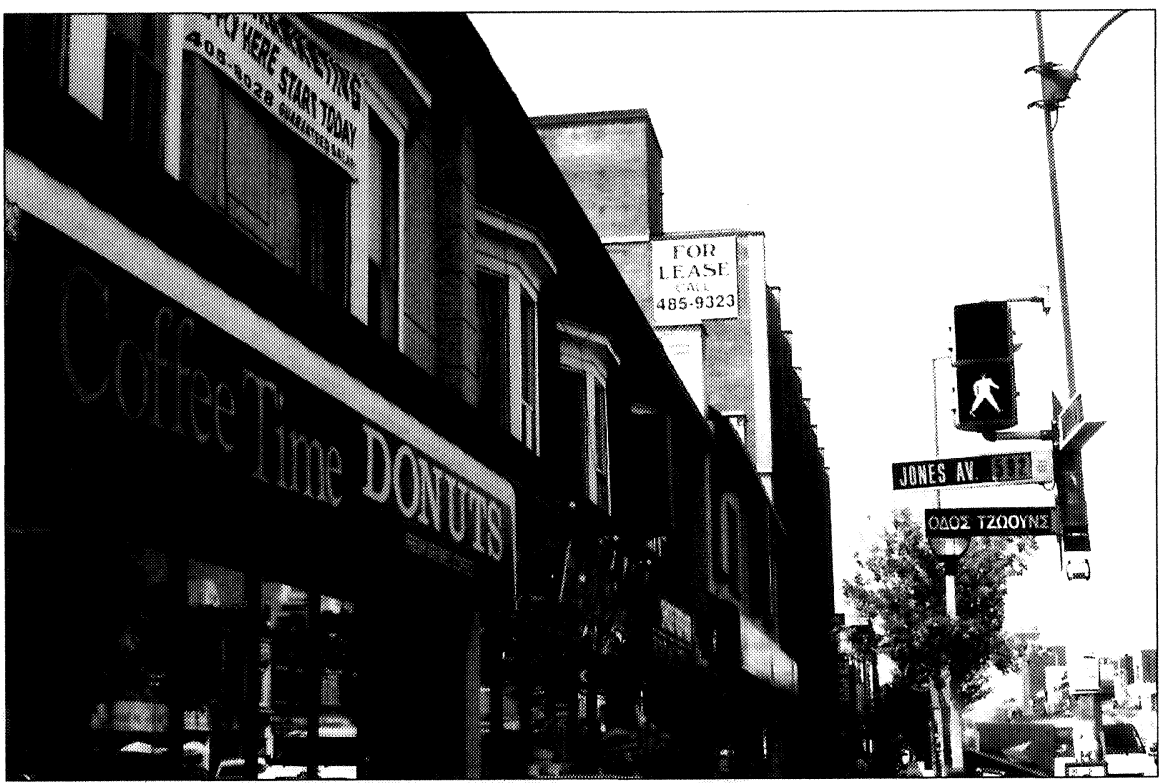

Figura 1.-La calle Jones en el barrio griego.

socialmente la diversidad a lo largo de tres ejes de análisis distintos: la transformación del horizonte, el empleo de las fachadas y el uso simbólico de las aceras a la vista del público ${ }^{15}$.

El horizonte de la ciudad de Toronto está constituido, como he dicho anteriormente, por una línea bastante continua en la que predominan las tres alturas. En una vista panorámica de la ciudad, esta línea se percibe claramente interrumpida por un conjunto de rascacielos que se agrupan en el distrito financiero de la ciudad (fig. 2).

Este conjunto de rascacielos constituyen la transformación más profunda en la línea del horizonte de la ciudad. Al nivel de los peatones se perciben como se muestran en la fotografía (fig. 3).

Como se puede apreciar en la imagen, la línea horizontal ha sido radicalmente transformada hasta convertirse en una vertical. Por otro lado, los símbolos étnicos están absolutamente ausentes y el espacio se percibe como una mole marrón-grisácea que se impone de forma definitiva a la mirada del peatón, privándole prácticamente de la vista del cielo. Des-

15 Incluyo en mi análisis los espacios privados, como casa particulares, y los semiprivados, como tiendas y oficinas, pero los trato como imagen pública en la medida en que ofrecen su aspecto externo a cualquiera que pasee por el espacio público propiamente dicho. 


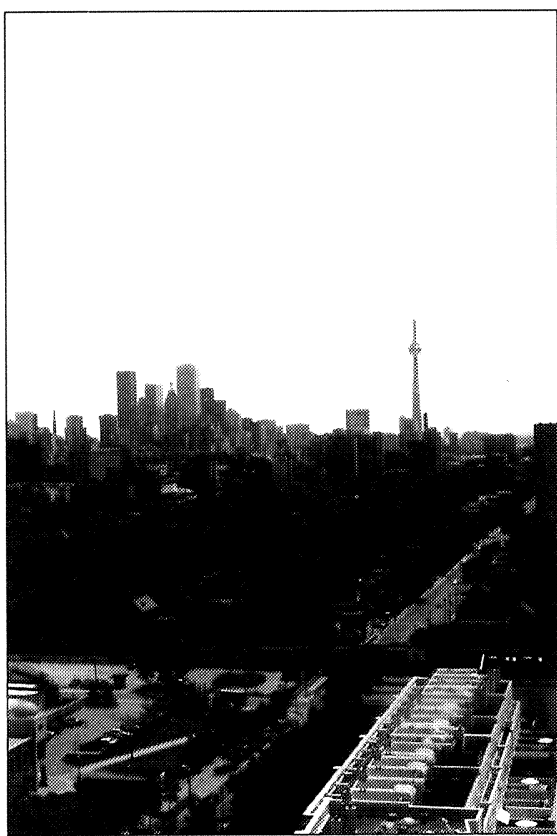

Figura 2.-Vista panorámica del centro de la ciudad de Toronto.

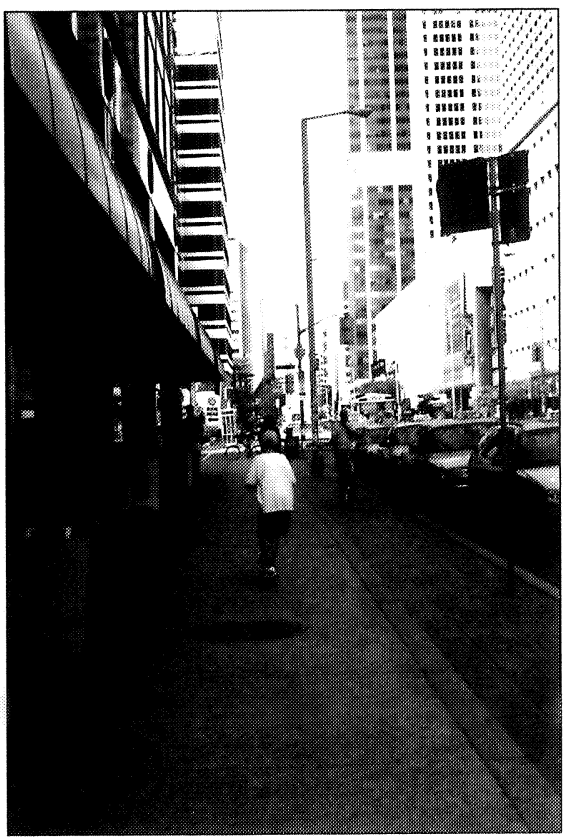

FIGURA 3.-El horizonte de los peatones en la zona de los rascacielos.

de mi punto de vista este uso del espacio público representa la transformación y la apropiación más radical del horizonte de la ciudad.

En los últimos años, el patrón de asentamiento a tres alturas, es interrumpido, además de por los edificios aislados de oficinas, por una serie de rascacielos de viviendas (o condominios) que comenzaron surgiendo en zonas residenciales de clase media alta, más alejadas del Downtown, como respuesta a un boom especulativo, provocado por la confluencia de distintos factores, entre ellos, la absorción por parte de Toronto de capitales nacionales (anteriormente asentados en la ciudad de Montreal) e internacionales (como consecuencia, por ejemplo de la salida de Hong Kong, cuando, recientemente, terminó el domino británico sobre la ciudad). Esta transformación del espacio de la vivienda, y por lo tanto del horizonte, se puede observar en la fig. 4, y ha llegado a afectar el corazón mismo del Downtown. En la calle Bay, cerca de la confluencia con Bloor se están construyendo, en este momento ${ }^{16}$, viviendas de lujo en rascacielos que prometen al futuro cliente comunidades exclusivas de

${ }^{16}$ Hasta ahora sólo son visibles los enormes cimientos y los carteles de propaganda. 
recreación y espacios verdes en el interior del recinto delimitado por los edificios. El disfrute de estos servicios comunales queda absolutamente restringido a los vecinos.

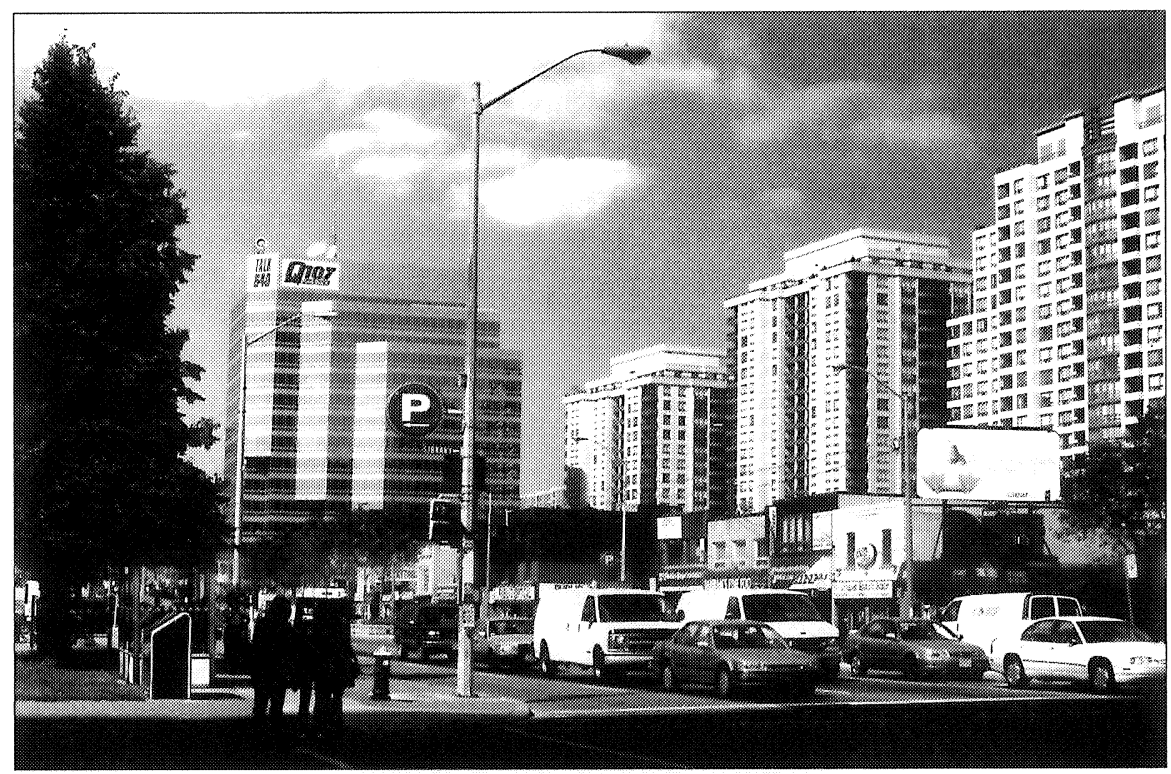

FIGURA 4.--Rascacielos residenciales de construcción reciente.

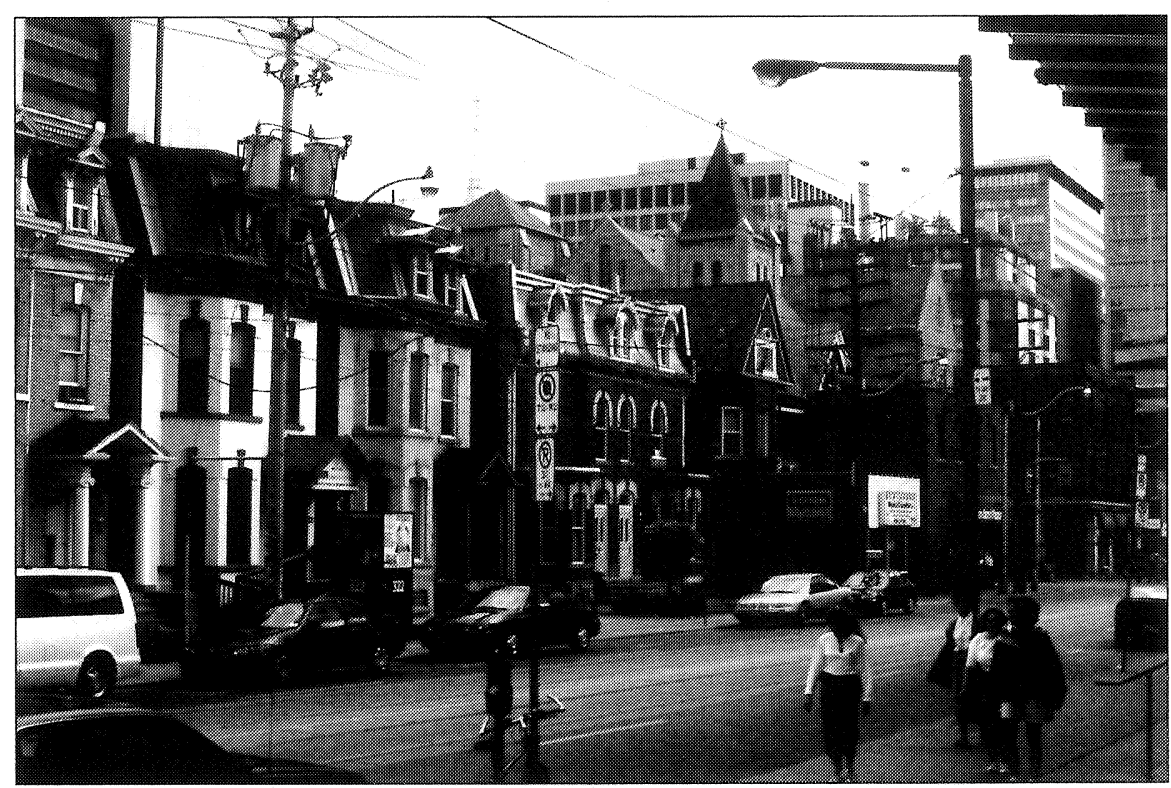

Figura 5.-Aspecto de una calle en una zona de clase media en el centro de Toronto. 
Otra forma de analizar la apropiación del espacio público consiste en dirigir la mirada a las fachadas. Ya se ha podido apreciar el aspecto anodino que presentan los rascacielos, voy a prestar ahora atención a las fachadas de tres alturas que son las que prevalecen en la ciudad (fig. 5). Existen varios mecanismos para apropiarse de la imagen de las fachadas y emplearlas como un escaparate de cara al público. Una de ellas, la más generalizada en los barrios de clase media, consiste en emplear elementos arquitectónicos que interrumpen la monotonía de las líneas, y combinar distintas tonalidades de color para resaltarlos.

La zona conocida como "barrio gay" representa un ejemplo de la misma estrategia pero empleada de forma mucho más audaz:
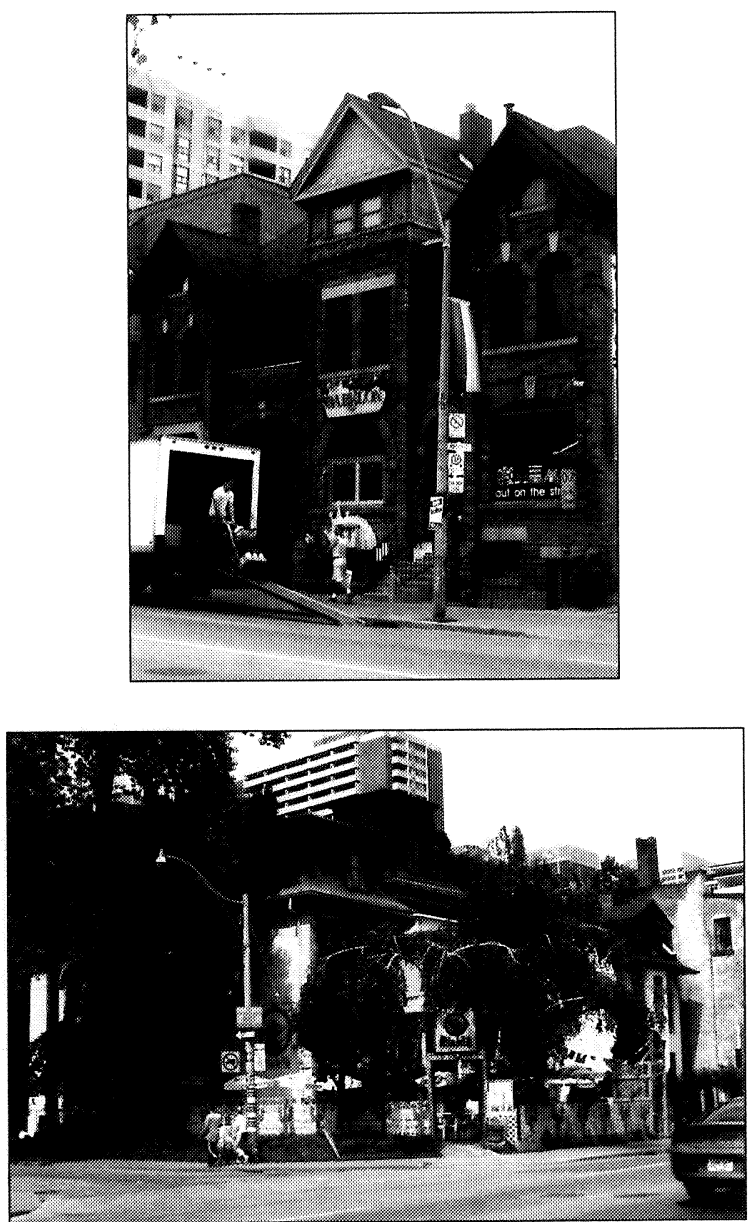

FIGURAS 6 y 7.-Fachadas típicas en el "barrio gay". 
Estas fachadas traslucen un nivel económico capaz de afrontar el desembolso de la restauración de los edificios y, además, el empleo profuso de la pintura en la fachada, que la trasforma radicalmente captando la mirada del visitante. La llamada de atención que supone el empleo de este espacio de cara al público está expresada de forma tan llamativa que casi automáticamente se puede asociar a la reivindicación. El colorido en arco-iris, bandera representativa del movimiento gay, no sólo se muestra en los colgantes repartidos por todo el barrio, sino que se aplica a las mismas paredes de los edificios, especialmente en los públicos. Ésta es, a la vez, una forma de marcar el espacio para delimitar un determinado comportamiento social, estableciendo unas fronteras, en el interior de las cuales el visitante puede observar, con mayor frecuencia, gestos que indican una relación de pareja entre hombres (no he observado lo mismo entre las mujeres).

En barrios más modestos, las fachadas son más monolíticas: la construcción es así más barata y la manera de transformarlas también lo es, lo que la convierte, al mismo tiempo, en más efímera. Se trata de colocar encima materiales empleados en la fabricación de carteles: cartón, madera, plástico, papel, etc.

Es precisamente en estos elementos donde se muestran los símbolos étnicos.

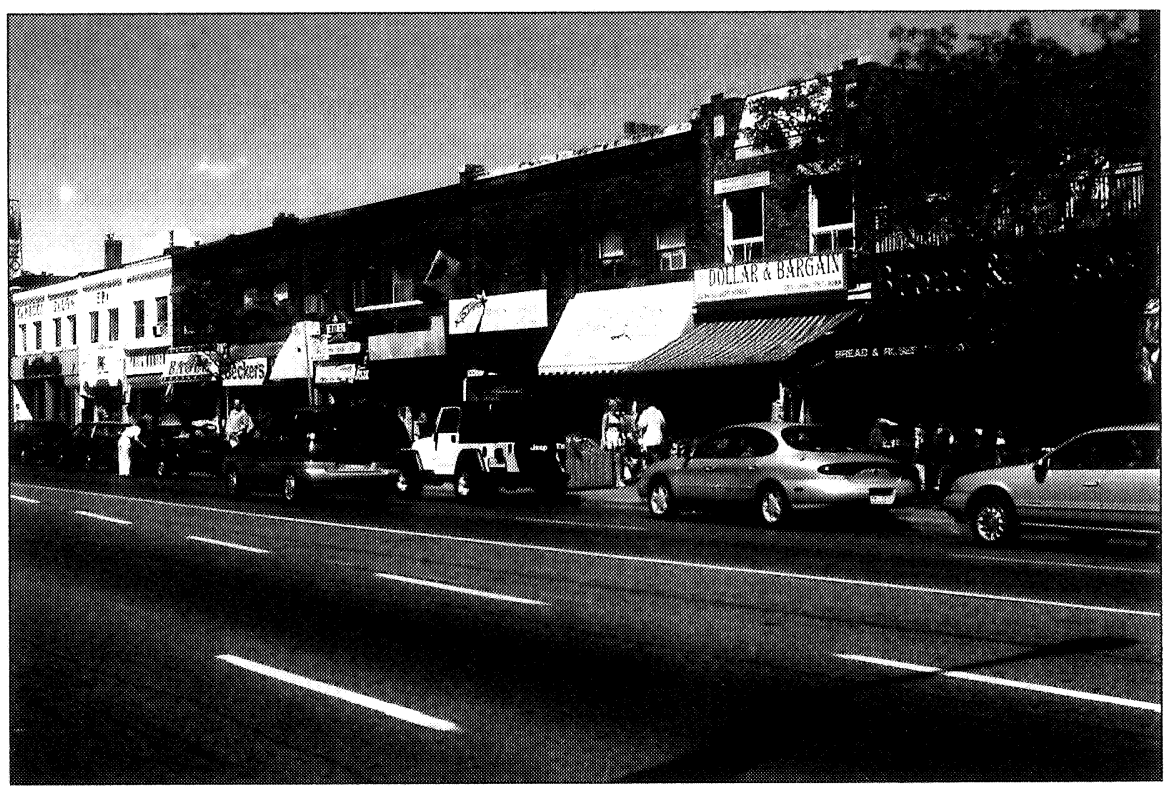

FigURA 8.-Fachadas de una calle en un barrio más modesto. 


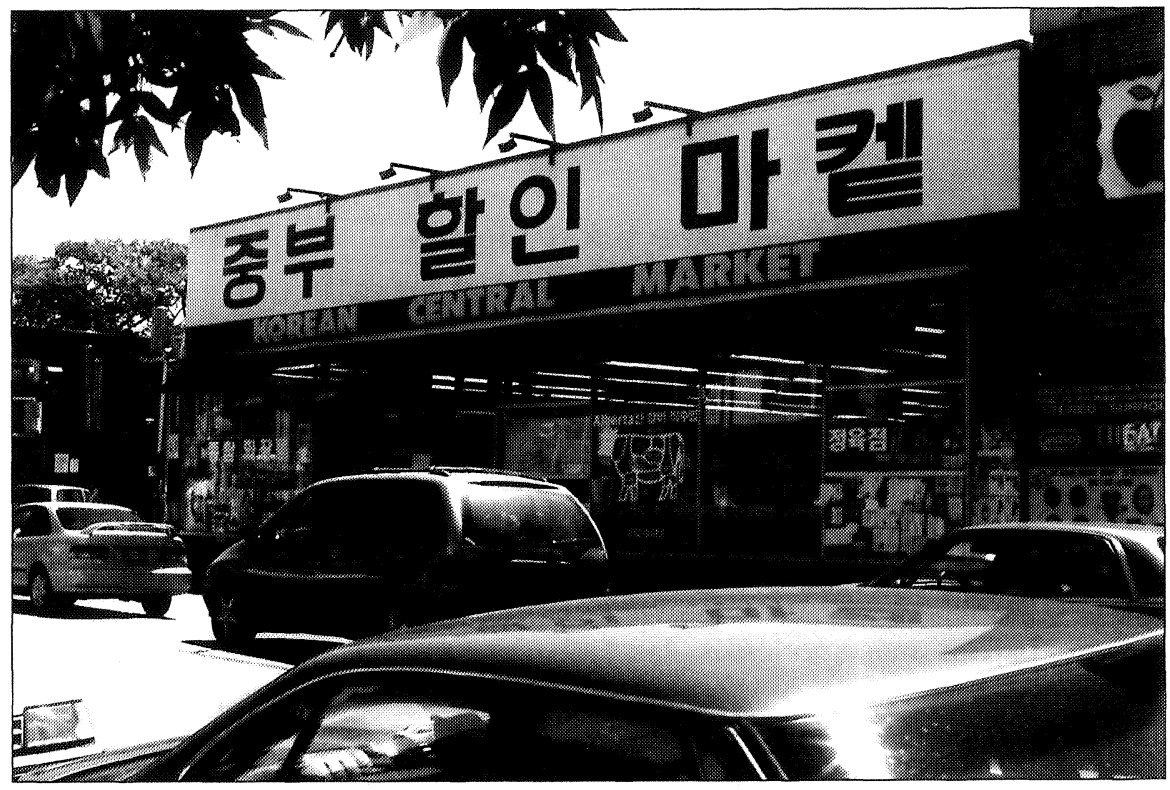

FiguRA 9.-Barrio coreano.

En la mayoría de estos barrios son las paredes de los bancos los que más llaman la atención, transformando su apariencia (figs. 10, 11 y 12). En los barrios étnicos se convierten en verdaderos escaparates de la etnicidad, independientemente del origen de los propietarios, lo que denota que, en estos lugares, la etnicidad se convierte en una moneda de cambio, porque atrae clientes y uhace negocios" (el caso del Royal Bank en el barrio chino es el más sobresaliente, porque se trata del banco más importante de Canadá, con representaciones en todo el territorio).

Esta misma idea se puede aplicar a los restaurantes, pero de manera mucho más generalizada, porque lo étnico, cuando se trata de comida, atrae clientela de todas partes de la ciudad y no solamente de un grupo. Algunos de estos barrios se convierten así en escaparates de la diversidad para, de nuevo, "hacer negocios".

Por último, el empleo de las fachadas más sorprendente es cuando se esconden a la vista de manera deliberada, dejando entrever más que mostrando, y provocando, sin embargo, un efecto mucho más llamativo.

Esta fachada (fig. 13), atrincherada entre verde, recorta la silueta quebrada de los tejados, apropiándose del horizonte a una mayor altura y, al esconder, juega con la imaginación del observador consiguiendo precisamente el efecto contrario: captar la atención sin revelar información. La vegetación evoca, por un lado, exceso de espacio, por el otro, perma- 

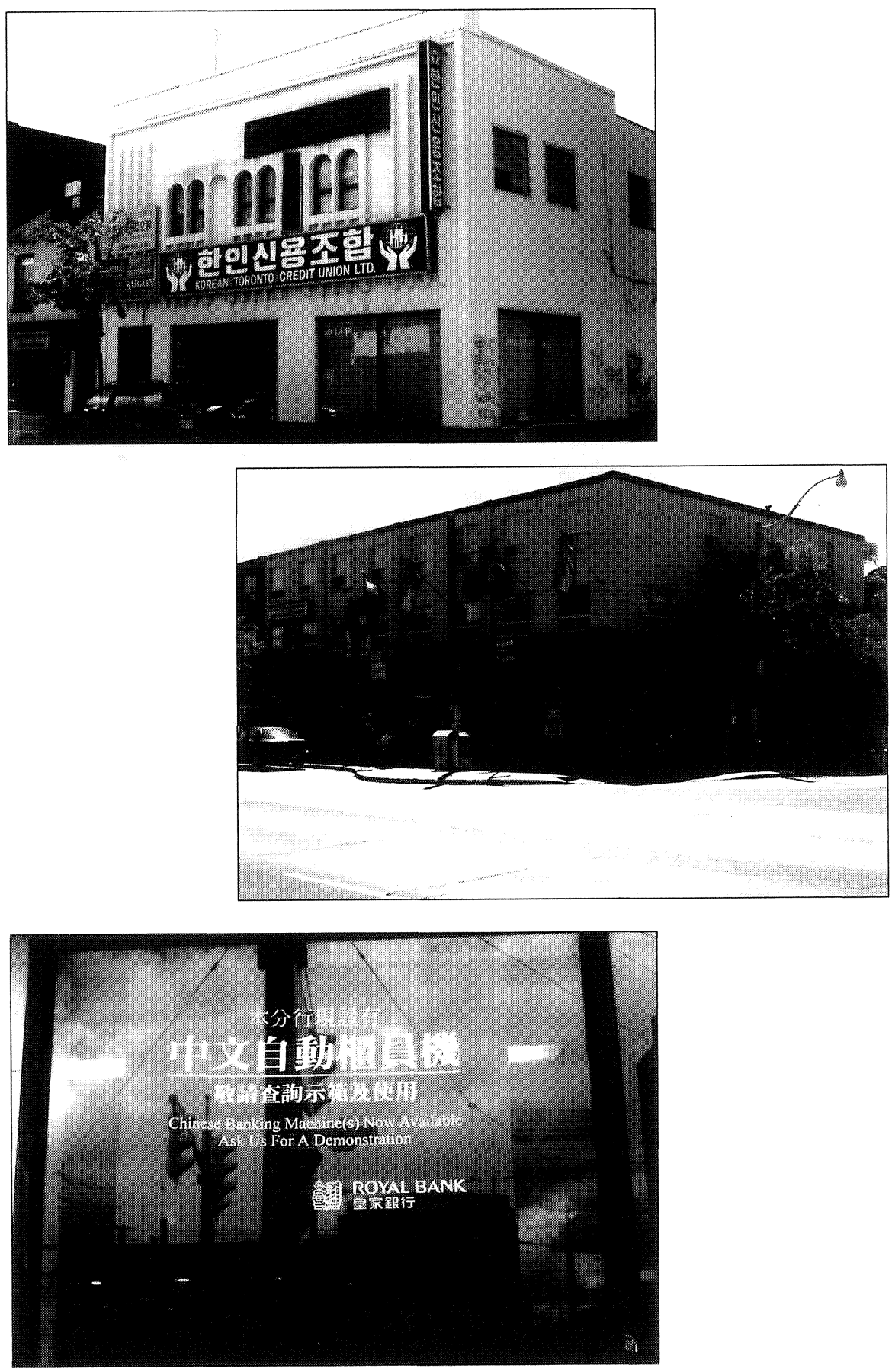

FiguRAS 10,11 y 12.-Bancos en los barrios coreano, ucraniano y chino respectivamente. 
nencia y durabilidad. La fotografía permite apreciar además una transformación mucho más profunda del espacio público, que no tiene nada que ver con las fachadas, aunque consigue el mismo efecto que éstas.

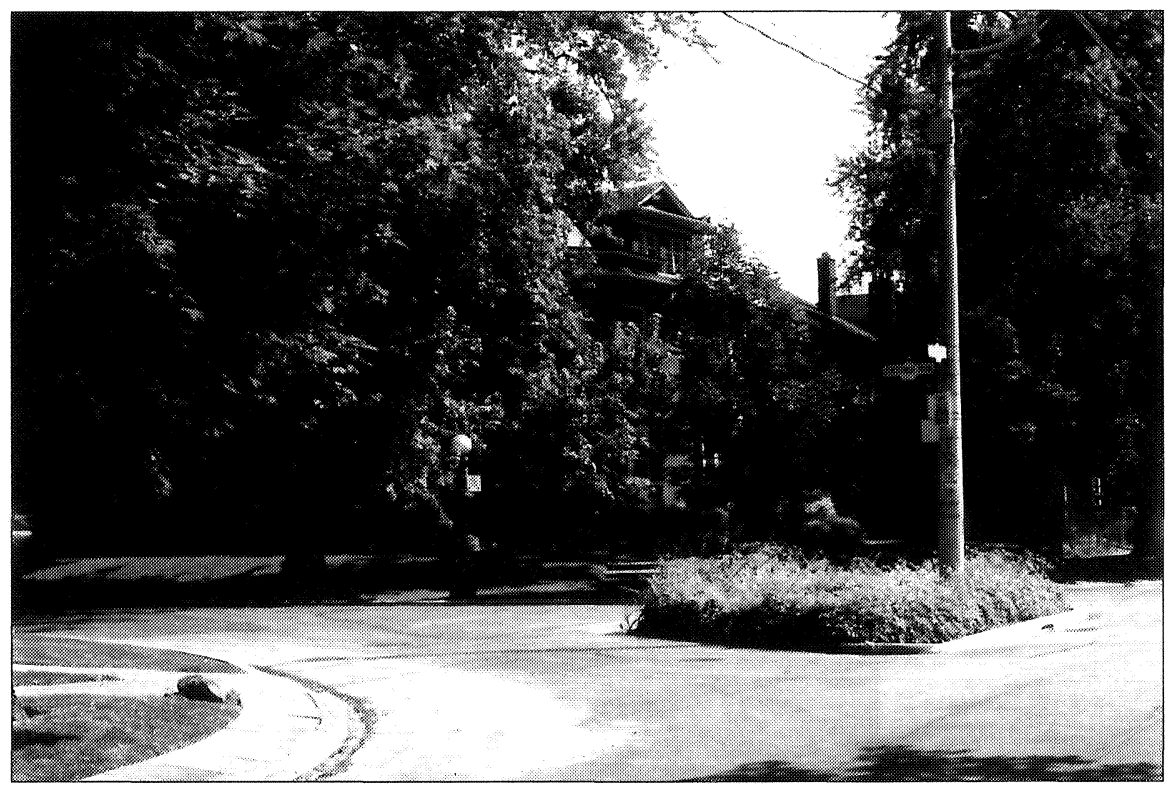

FiguRA 13.-Fachada en el barrio étnico inglés de Rosedale.

Al hacer la introducción sobre la ciudad de Toronto en este apartado, afirmé que el espacio se distribuye en una cuadrícula perfecta que se ordena en torno a dos ejes, dejando al margen las imposiciones de la geografía en las orillas del lago Ontario. Pues bien, esta imagen revela una excepción a esta norma. Las calles en el barrio, a pesar de que se encuentran en el corazón del Downtown, no son rectilíneas ni se cruzan en ángulos de $45^{\circ}$ como en el resto de la ciudad, sino que son curvas, quebradas y sinuosas, lo que revela una transformación profunda en el patrón de ordenamiento, y por supuesto habla del poder de sus habitantes para imponerlo. De manera que los vecinos originales del distrito han dejado su huella de una forma tan profunda que representa el extremo opuesto al del escaparate de carteles, alfabetos y colores del resto de los asentamientos.

Cerca de este barrio, exactamente en Forest Hill, se encuentra la Casa Loma, construida a principios del siglo $\mathrm{xx}$ como residencia por su propietario, quien impuso en el paisaje un edificio concebido al modo de los castillos europeos, y adelantándose a la filosofía que caracteriza la arqui- 


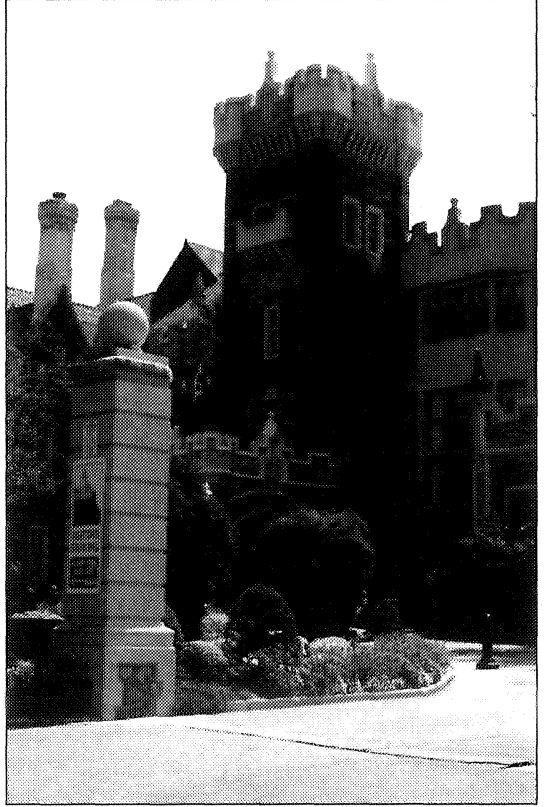

FIGURA 14.-Casa Loma.

tectura postmoderna. Hoy día es uno de los enclaves turísticos de Toronto, porque funciona como museo.

El barrio de Rosedale representa igualmente un extremo a la hora de analizar el uso de las aceras.

Como se puede apreciar en las figuras 15,16 y 17 , las aceras son enormes aunque el espacio para el peatón es muy estrecho: un pequeño camino perfectamente delimitado. De manera que su uso es puramente ornamental y además tiene la función de alejar al que camina de la vivienda por la que pasa y al mismo tiempo que incrementa la distancia entre la calle y la fachada. Los árboles a lo largo de las aceras esconden, además, el tráfico que discurre. No existen tiendas abiertas al público, ya que éstas se concentran en los márgenes del distrito, y lo mismo ocurre con los cafés y los restaurantes, que no flanquean la calle principal, como es

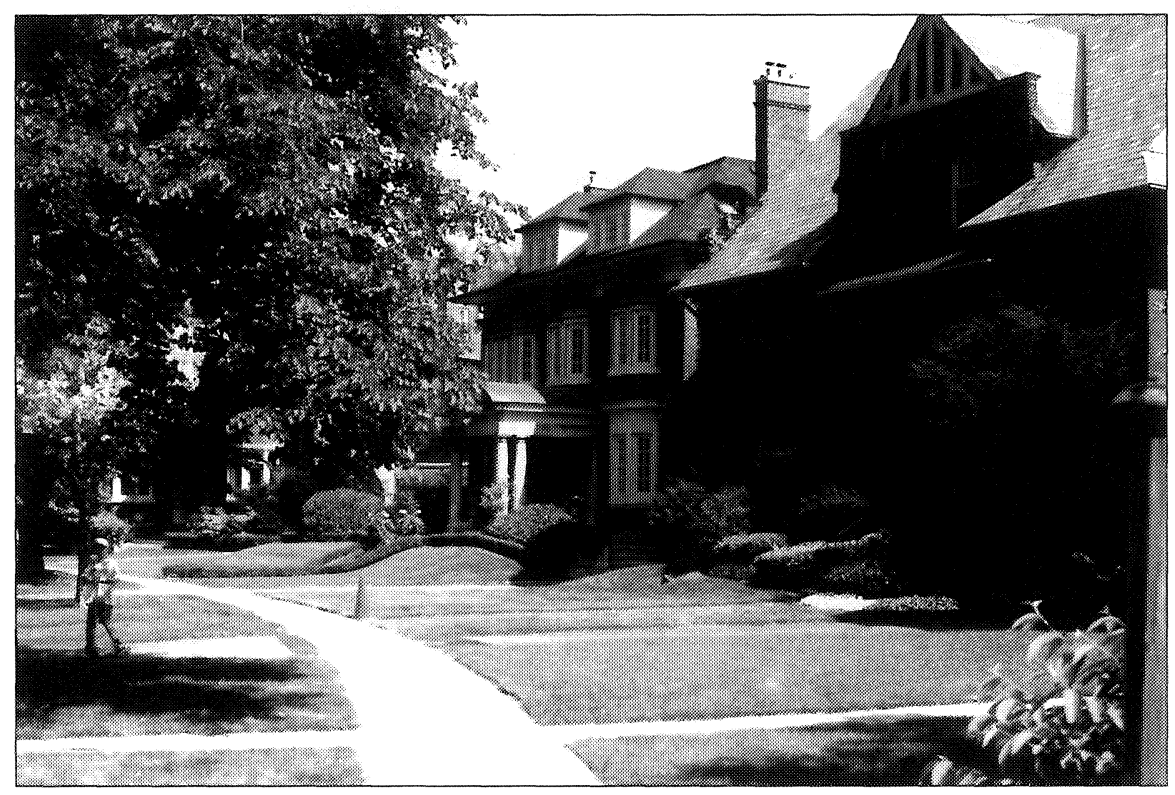

Figura 15.-Calle Crescent Rd., en el barrio de Rosedale. 

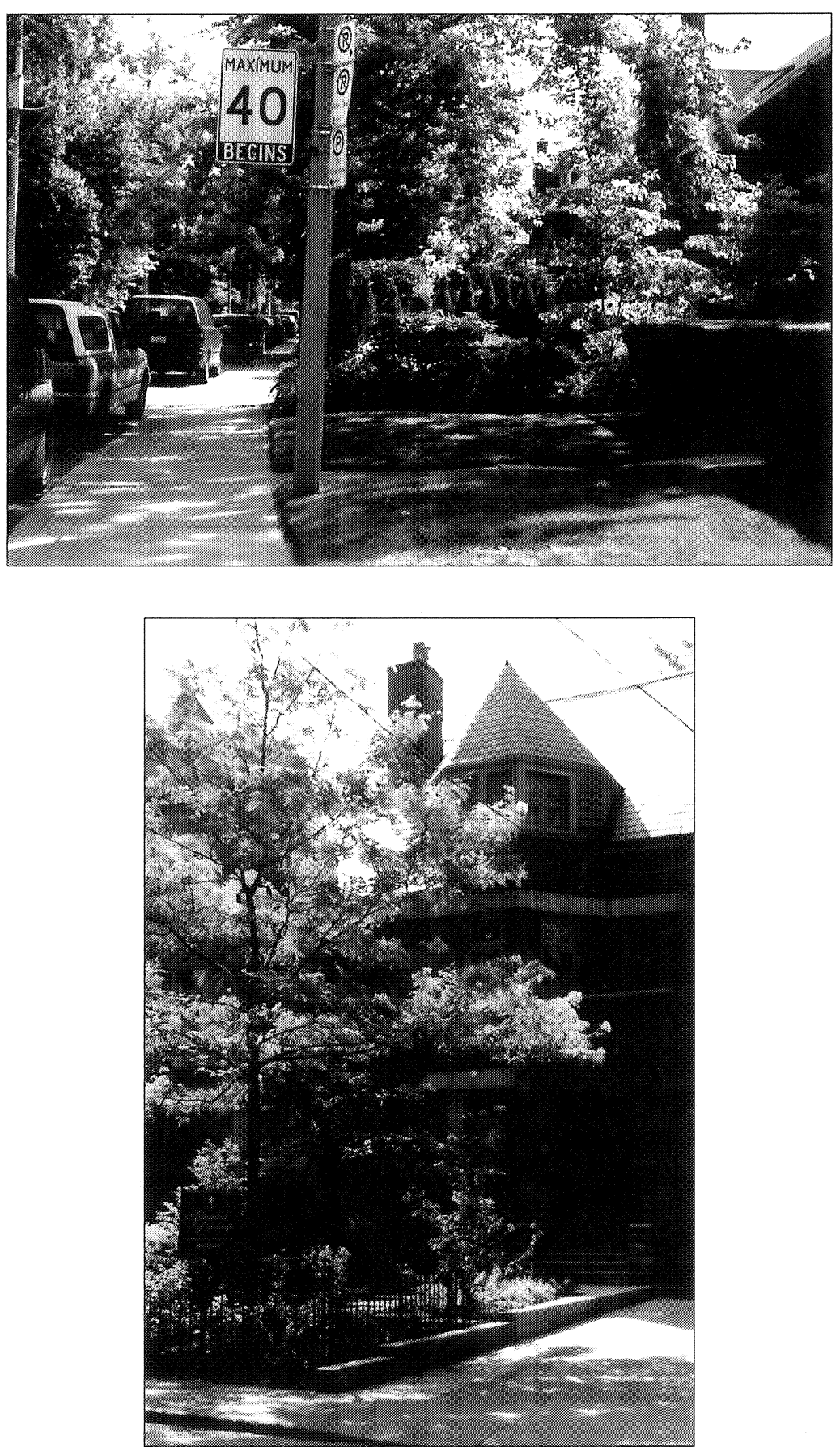

Figuras 16 y 17.-Las aceras en Rosedale. 
corriente en el resto del Downtown de Toronto. De la misma forma, el acceso al transporte público sólo se puede hacer en los extremos, porque ni los autobuses lo atraviesan, ni existen estaciones de metro en el interior de su recinto.

Compárese este uso de las aceras, por ejemplo, con el de la arteria principal del barrio chino, donde el espacio reservado a los peatones es
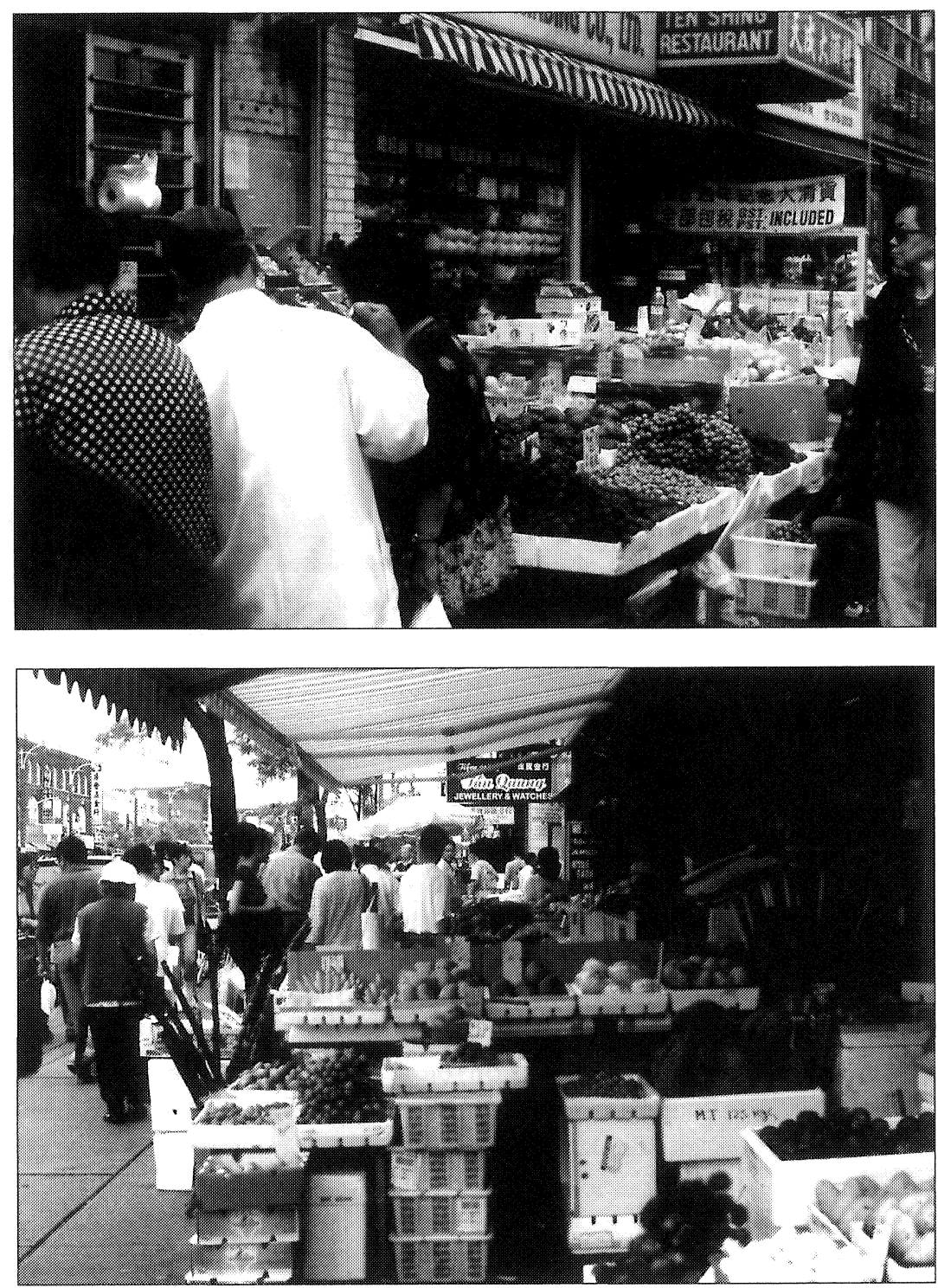

FIGURAS 18 y 19.-La aceras en la calle principal de Chinatown. 
invadido, aunque solamente en horario comercial, y hasta los sótanos se transforman en fachadas, convirtiendo la acera en escalera.

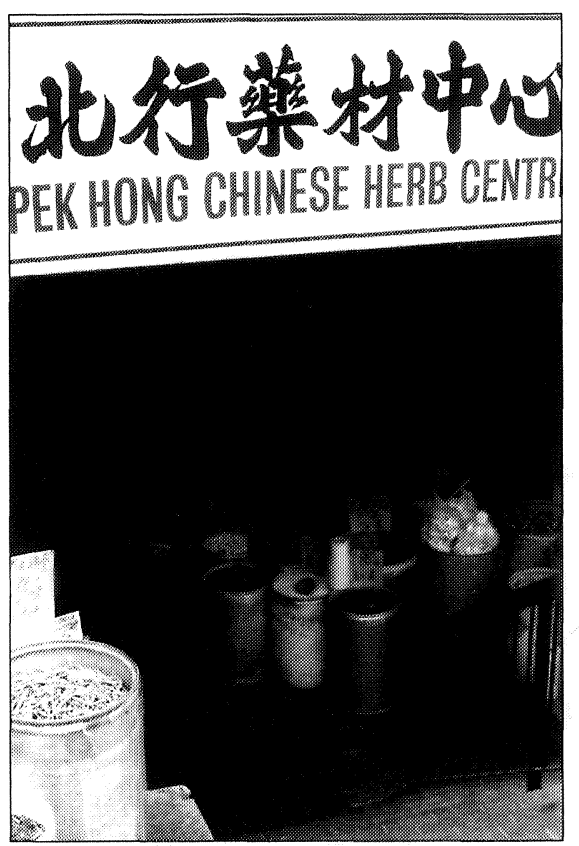

FIGURA 20.-Una tienda en un sótano del barrio chino.

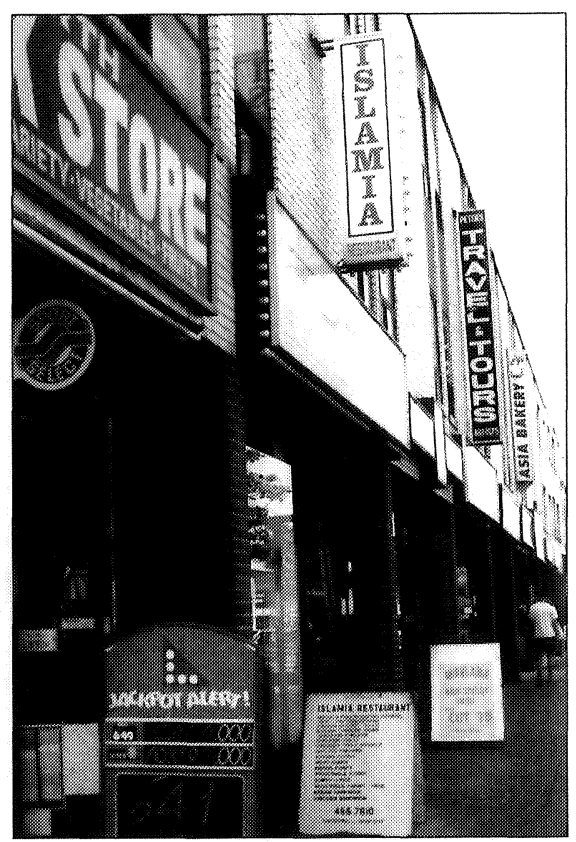

FIGURA 21.-Calle principal en el barrio indio.

E incluso con la calle principal del barrio conocido como Little India, donde se observa una irrupción en la acera igualmente paralela al horario de comercio, pero menos agresiva para el peatón.

El extremo opuesto al uso de las aceras en Rosedale lo constituye, sin embargo, el barrio conocido como Kensington Market. Fue originariamente el distrito de los inmigrantes, se considera quizá el barrio más multicultural de Toronto (así lo anuncian las guías), pero es, sin embargo, una zona comercial con un acento semejante al Rastro de Madrid; es decir, estamos ante un multiculturalismo de tiendecitas y puestos (de comercio, una vez más). La invasión de las aceras por parte de los comercios es extraordinaria, de manera que los peatones, para transitar, tienen, a su vez, que invadir las calzadas. Quizá se puede considerar el lugar de Toronto de más difícil acceso para los coches.

Se trata de un mercado abigarrado de productos procedentes de casi todo el mundo, mezclados en una misma estantería o en un mismo colgador de perchas. Si es representativo de algo, creo que lo es, extraordi- 
nariamente, de un multiculturalismo de productos: música, ropa, comida, etc. Casi todos ellos tiene un denominador común: son objetos "de moda" y son baratos.
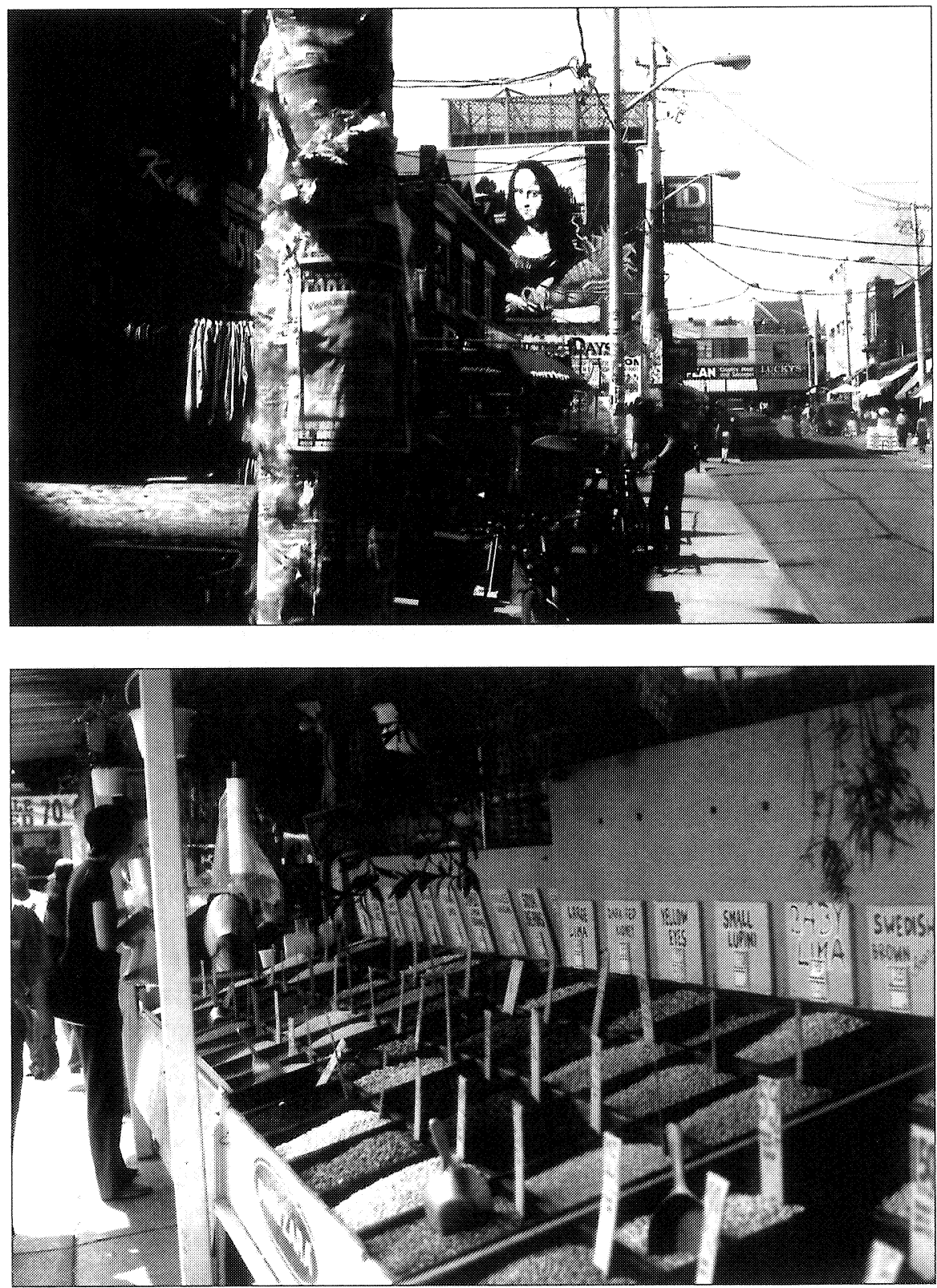

FIGURAS 22 y 23.-Dos imágenes de las aceras en Kensington Market. 
Mi ejemplo de análisis del uso del espacio no ha pretendido ser exhaustivo: ni el lugar del que dispongo ni el estudio realizado me lo permitirían. He elegido tres formas o coordenadas distintas para observar de manera pública el espacio de la ciudad de Toronto y he ofrecido los ejemplos que me han resultado significativos, intentando siempre presentarlos de una forma comparada para explorar los contrastes. Estos contrastes me han sugerido las siguientes conclusiones:

En primer lugar, que el espacio público se usa de forma diferente en distintos lugares de la ciudad y que estas diferencias de uso responden a los intereses, tanto como a las posibilidades de imponer una determinada imagen al público.

En segundo lugar, que las transformaciones más profundas de ese espacio se perciben disociadas de los elementos étnicos. He identificado como más radicales aquéllas que modifican completamente el horizonte imponiendo una línea vertical (rascacielos), por un lado, y las que modifican la estructura del patrón de asentamiento reticular de las calles de la ciudad (estructura urbanística en el barrio de Rosedale, o barrio inglés), por otro. En ninguno de estos dos casos se puede percibir, de forma pública, una sola señal étnica que nos hable acerca del origen de sus propietarios o de sus clientes, sea cual sea éste.

En tercer lugar, que estas señas étnicas están emplazadas en lugares de la ciudad con una capacidad de transformar el espacio mucho más limitada, bien porque se realice de una manera más barata y efímera (colocando sobre la fachada carteles, banderas, toldos, etc.), bien de forma temporal, y ésta en dos sentidos: fácilmente sustituible, o de acuerdo a un horario (como hacen algunos comercios).

En cuarto, que los lugares más transformados disponen, en general, de una mayor cantidad de espacio, y por lo tanto lo "derrochan. Mientras que los que han sufrido una transformación más superficial o más efimera, que al mismo tiempo se podría considerar que constituyen el escaparate de la etnicidad, disponen de menos espacio, y que por ello, éste se aprovecha al máximo, llegando incluso a invadir lugares destinado a otros usos. Este fenómeno es particularmente visible en el empleo de las aceras.

Por último, y como consecuencia de todo lo anterior, que las señales étnicas en la ciudad de Toronto modifican de una forma limitada el aspecto de la ciudad: bastante visible y llamativa, pero superficial. Que los cambios más profundos, así como el poder para realizarlos, no están en relación con las imágenes que evocan etnicidad o diferencia, sino al margen de ellas. No conozco ningún rascacielos con la más mínima señal étnica, con una sola excepción, el edificio que aloja el hospital Mount 
Sinai (emplazado en el corazón del antiguo barrio judío, hoy zona de hospitales, y que representa el único reducto de la memoria del origen étnico del barrio). Curiosamente, el nombre del hospital, que es la única referencia al origen del barrio, se muestra en un cartel que está colocado sobre la fachada y tiene unas dimensiones desproporcionadas en relación al tamaño de la construcción.
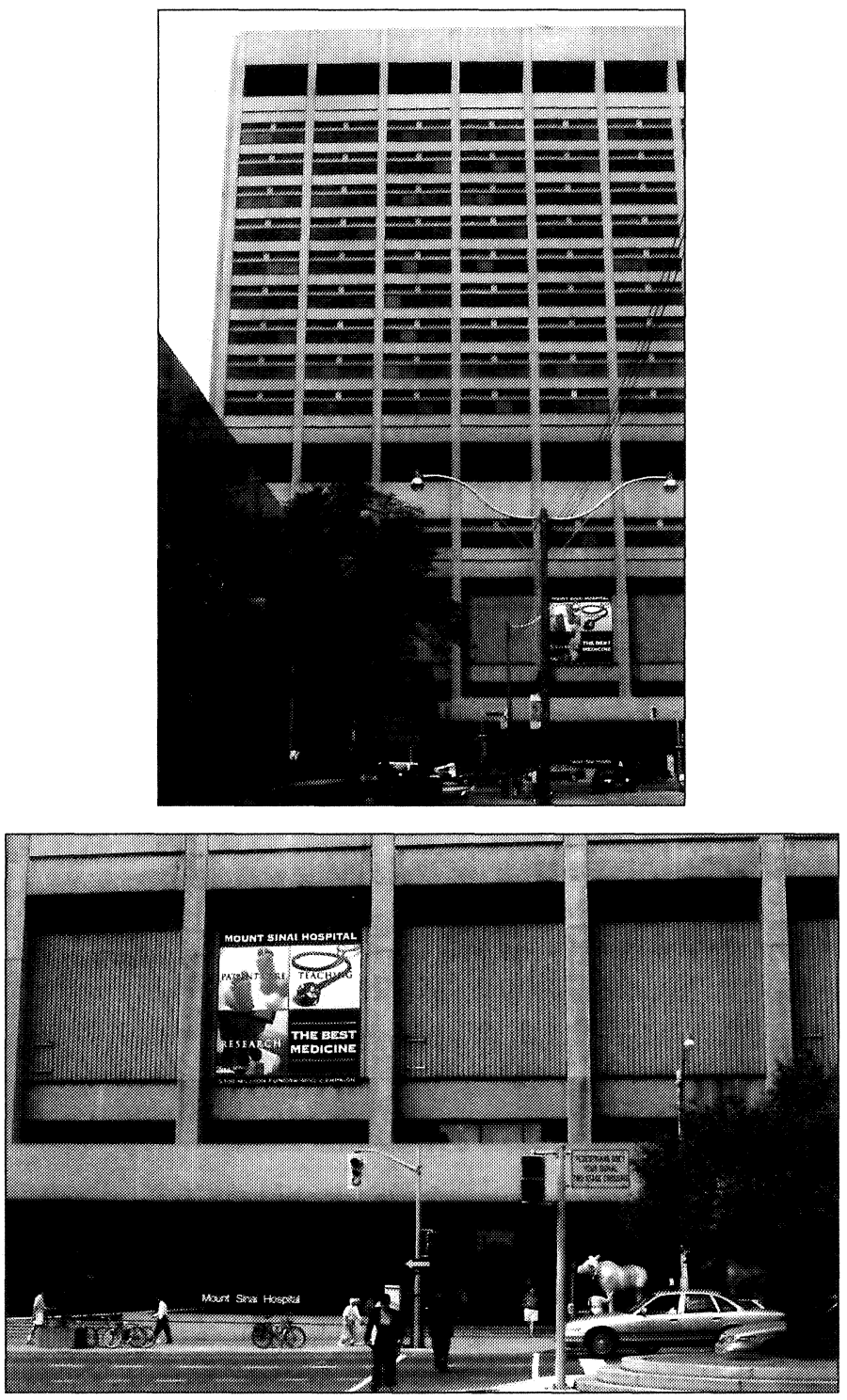

Figuras 24 y 25.-Hospital Mount Sinai. 
Parece como si el poder y el dinero a gran escala borraran todo símbolo étnico, como si las diferencias que celebra el modelo multicultural quedaran desplazadas hacia otros lugares más baratos y más efímeros, donde, ahí sí, resultan evidentemente un atractivo para los negocios. Pero esta impresión no debe inducir a error: no se trata de que un ciudadano de Toronto de origen chino, por poner un ejemplo concreto, no posea $o$ pueda poseer un rascacielos o una mansión, lo único que significa es que sea quien sea su dueño, no hace alarde de sus diferencias étnicas, al menos a la vista del público, no marca sus posesiones con "Símbolos multiculturales". Las razones de ello tienen, necesariamente, que ser muy complejas, y por lo tanto escapan a los objetivos generales de este trabajo. Pero sí parece plausible interpretar que el poder y el dinero no parece que participen, de una manera evidente, del desfile multicultural.

En este sentido coincido plenamente con el análisis de Signorelli (1999: 18-20), quien, a partir de un análisis comparativo entre el metro de París y el de ciudad de México, afirma que:

La diversidad es relacional, está producida en relación a las condiciones del contexto social en que se da, es jerarquizante y jerarquizada porque implica juicios de valor y relaciones de poder. Pero es también relativa ya que lo que en un contexto es diverso, en otro contexto es normal. Agregamos que es dinámica, en el sentido de que no nacemos diversos, pero somos producidos como tales: lo que significa que se puede dejar de ser diferentes, ya sea a nivel individual, integrándose en la categoría de los normales, o integrándose en un contexto donde la diversidad $\langle\mathrm{X}>$ ya no es percibida como tal; como a nivel colectivo, en la medida en que cambian las condiciones del contexto social que ha producido las características que, en el contexto mismo, definen la diversidad (Ibid.: 20)

\section{ALGUNAS CONTRADICCIONES A MODO DE CONCLUSIÓN}

Para empezar quiero hablar de una contradicción propia. Antes de comenzar este trabajo, cuando lo propuse y mientras lo desarrollé, yo misma estaba convencida de que, a pesar de todas sus contradicciones y de las críticas que desde distintas perspectivas se le pudieran hacer y en las que asomaba un cierto desencanto, la instrumentación política de un modelo multicultural en Canadá constituía un primer paso firme para solucionar los problemas derivados de una tendencia, hoy innegable, en las sociedades contemporáneas, al menos en los países ricos: la diversificación étnica y cultural de la población en las grandes ciudades. Sin embargo, mi argumentación me ha llevado, a pesar de mi planteamiento inicial, a conclusiones contrarias a esta idea. 
El análisis del material recogido en mis dos campañas de trabajo en Canadá, y que como dije estuvo planteado en tres niveles distintos (los discursos, las imágenes y las reflexiones sobre lo que significa ser canadiense), me conduce a pensar que el modelo multicultural canadiense, tal y como ha sido concebido y desarrollado políticamente en los últimos años en el país, ha promovido una imagen superficial que emplea las diferencias de una forma propagandística, porque las reduce (y en este sentido sí ha resultado efectivo) a la incorporación de hábitos de comida, de vestido y de baile.

Este tratamiento superficial de las diferencias elude cuestiones mucho más complejas que el modelo ni siquiera formula, porque no las reconoce, y por lo tanto, los problemas derivados de una convivencia multicultural se encuentran sin la posibilidad de ser detectados. No se proponen soluciones, porque ni siquiera se preve que la problemática pueda llegar a existir.

Eso no significa que el modelo multicultural sea del todo ineficaz, porque, al contrario, es muy efectivo en una dimensión: a modo de propaganda. Funciona, como lo hicieron los folletos propagandísticos del siglo $\mathrm{XIX}$ y principios del siglo $\mathrm{XX}$, para atraer inmigración. $\mathrm{Y}$ en este sentido funciona muy bien. Especialmente en un mundo caracterizado por procesos que estamos de acuerdo en denominar de "globalización". Cuando los medios de comunicación llegan a audiencias mucho más amplias y el transporte es mucho más barato, la propaganda es mucho más contundente. Como tal, el modelo multicultural provoca, en determinados lugares, y Toronto es uno de ellos, una enorme diversificación de la población. En este sentido, este proceso bien puede ser un ejemplo de la "otra cara de la moneda" de los efectos unificadores del proceso de globalización, a los que, con demasiada frecuencia, es a los únicos que se suele aludir, olvidando la dimensión contraria que representa la inmigración.

El modelo multicultural ha atraído a Toronto gente de los más alejados rincones del globo. La relajación de las normas de inmigración en 1967, como consecuencia del inicio de las ideas políticas multiculturalistas, ha permitido el acceso de algunas personas (con una determinada "educación", y cierto nivel económico, indudablemente) procedentes del llamado "Tercer Mundo" que, hasta ese año, tenían vedada la entrada al país en virtud de su origen.

Esta variedad de orígenes en la población de Toronto es, sin duda, un efecto (entre otros factores) de la política multicultural. Ahora bien, una vez que llegan bajo la promesa de igualdad de oportunidades, de justicia social y respeto cultural, esas gentes encuentran pocos mecanismos para resolver las contradicciones que existen entre las normas que 
traen consigo y las que ya funcionan en Canadá (hablo de las importantes, y excluyo, desde luego, sus hábitos de comer, vestirse y bailar). Me refiero a los sistemas jurídicos, a las normas religiosas contradictorias, a las relaciones entre los sexos, a la distribución del poder, a la interacción social, etc., que plantean contrastes profundos y cuyo respeto, algunas veces, implica negociar cambios profundos en la estructura social que parecen imposibles (¿o no lo son?).

Lo que parece es que, a excepción de unos cuantos hábitos superficiales, la población inmigrante en Toronto se encuentra en la misma encrucijada que el resto de la población inmigrante en otros países, porque el modelo multicultural no resulta muy efectivo a la hora de respetar, celebrar, e incluso profundizar en unas normas sociales que se hallan en contradicción con las locales. El intenso proceso de transformación al que se ven sometidas la primera y, sobre todo, la segunda generación de inmigrantes en Toronto, no creo que sea facilitado en absoluto por el modelo multicultural. La necesidad de integrarse y olvidar las señales étnicas, reduciéndolas exclusivamente a la vida privada, o usarlas para atraer pequeños negocios, parece que es, al igual que en otros lugares, una condición para ascender en la escala económica y de poder de la sociedad canadiense, o al menos esto es lo que muestra un análisis de la imagen pública del espacio.

Sin embargo, a pesar de todo ello, la política multicultural como bandera de propaganda, sí puede estar funcionando como un instrumento de cambio, en la medida, y sólo en la medida, en que diversifica la población, y por lo tanto, el material a partir del cual se producen las relaciones sociales: me refiero a las personas mismas, a los ejemplos individuales que construyen, y transforman, día a día y de manera casi imperceptible, la vida diaria en la interacción social, y que negocian sus diferencias en la medida que les permiten sus posibilidades. Veamos a este respecto un fragmento de uno de los discursos recogidos en las entrevistas, que bien puede poner punto final al trabajo:

Informante: Por ejemplo, con los nietos míos, yo veo que el multiculturalismo en el nivel individual sí se puede hacer: Pasan de un idioma a otro, comen la arepa igual que comen las angulas. Francamente, ni saben que las angulas son húngaras y la arepa venezolana. No les importa además, ¡les gusta! [...]

Yo: ¿Y eso hubiera pasado lo mismo si tu familia se hubiera quedado (en tu lugar de origen)?

Informante: ¡No!

Yo: ¿No?

Informante: ¡No! porque el ambiente cultural, realmente, es más inclusivo [...] Aún cuando digamos que tenemos problemas con la definición del multiculturalismo, lo importante es que la población está abierta, está abierta a cosas diferentes. 
Que por supuesto hay que poner un límite. La palabra multiculturalismo incluye que se puede hacer todo. Sin embargo, tú no puedes matar gente porque en otra cultura esté permitido, ¿eh? Es decir, hay fronteras judiciales y naturales de cosas que sí se puede hacer y otras no. Lo que queda es lo que no hace daño, lo que no restringe la libertad del otro. Eso sí puede ser.

Yo: ¿Y las normas cambian? Es decir: ¿son siempre los mismos los que ponen las normas, o esto de que venga tanta gente de tantas partes del mundo, de alguna manera les ha hecho negociar?

Informante: No, hay muchos malentendidos. Aquí te puedo contar un cuento:

Hace muchos años vino una mujer con cuatro o cinco niños de [otro país]; simplemente porque su esposo, que tenía dinero, quiso mejorar la educación de sus hijos. Empaquetó a la mujer con los cinco hijos, para que estudiasen inglés, y los mandó a Toronto. Les alquiló una casa muy buena. Y allá estaba ella: sin hablar inglés, ni ella ni los niños. Entonces [mi hijo] iba frecuentemente en su bicicleta para ayudarla, para hablar, y para jugar con los niños, desde luego. Entonces un día nos llaman, que por favor que vaya [mi hijo] porque hay un problema con la policía. Dos horas después mi hijo regresa y: ¿Bueno, qué pasaba con la policía?, ¿para qué estaba la policía? Mi hijo dice, iqué sé yo, porque mataron una gallina! Bueno, a ver, ¿qué pasó? Lo que pasó fue que la señora quiso hacer un caldo de gallina. Un caldo de gallina se hace donde ella vivía comprando la gallina ¡viva!, matándola y, cuando el agua hierve, se despluma, y se mete dentro. Así es como está más sabrosa. La manera de matar una gallina donde vivía esta señora es coger la gallina por la cabeza y darle vueltas hasta que se le quiebre la nuca y la gallina esté muerta. Los vecinos, que vieron eso, interpretaron que lo que la señora hizo con la gallina...

Yo: La señora ¿de dónde sacó la gallina?

Informante: La compró en el mercado.

Yo: ¿Viva?

Informante: Sí, en Kensington Market. Ahí hay.

Yo: Ahá.

Informante: La tuvo además un día entero en el jardín, correteando, así que los vecinos se dieron cuenta de que la señora tenía una gallina. Después dándole una vuelta al cuello la mató. Y por eso, por maltratar a un animal, por torturar a un animal, los vecinos llamaron a la policía. Y ahora viene la cosa linda, donde el multiculturalismo se convierte en culturalismo regional. Vino la policía, y ¿qué hizo? ¿y qué dijo el policía? El muchacho contesta: ¡No hizo nada! Y, ¿qué pasó? El policía era un jamaicano, cuya señora madre siempre había matado las gallinas... ¡agarrándolas por el pescuezo y retorciéndoselo! ¡Y lo que le contaron le pareció lo más normal del mundo! Por lo tanto no hubo crimen en su opinión.

\section{BIBLIOGRAFÍA CITADA}

APPADURAI, ARJun. 1995. “Global Ethnoscapes: Notes and Queries for a Transnational Anthropology", en R. G. Fox (ed.), Recapturing Anthropology: 197-210. Santa Fe, Nuevo Mexico: School of American Research Press. 
- 1998. Modernity at Large. Cultural Dimensions of Globalization. Minneapolis, Minnesota: University of Minnesota Press.

BAUBÖC, RAINER. 1999. "Liberal Justifications for Ethnic Group Rights", en C. Joppke y S. Lukes (eds.), Multicultural Questions: 133-157. Oxford: Oxford University Press. Canadian Multiculturalism Act. 1998. Toronto: Federal Publications Inc.

HUSANI, ZORA. 1990. Muslims in the Canadian Mosaic. Edmonton: Muslim Research Foundation.

JOPPKE, CHRISTIAN, y STEVEN LuKes. 1999. "Introduction: Multicultural Questions", en C. Joppke y S. Lukes (eds.), Multicultural Questions: 1-24. Oxford: Oxford University Press.

KASHER, ROBERT J. 1997. Ethnic Toronto. A Complete Guide to the Many Faces \& Cultures of Toronto. Lincolnwood, Illinois: Passport Books.

KASHMERI, ZUHAIR. 1991. The Gulf Within. Canadian Arabs, racism and the Gulf War. Toronto: James Lorimer and Company Publishers.

Kostash, Myrna. 2000. The Next Canada. In Search of Our Future Nation. Toronto: The Canadian Publishers.

Palmer, Hazelle. 1997. “...But Where Are You Really From?" Stories of Identity and Assimilation in Canada. Toronto: Black Women and Women of Colour Press.

PÉREZ GARZón, JuAN SISINIO y OtROS. 2000. La gestión de la memoria. La historia de España al servicio del poder. Barcelona: Crítica.

SHACHAR, AYELET. 1999 "The Paradox of Multicultural Vulnerability: Individual Rights, Identity Groups, and the State", en C. Joppke y S. Lukes (eds.), Multicultural Questions: 87-111. Oxford: Oxford University Press.

Signorelli, Amalia. 1999. Antropología urbana. Barcelona: Anthropos.

SpinNer-Halev, JefF. 1999. "Cultural Pluralism and Partial Citizenship", en C. Joppke y S. Lukes (eds.), Multicultural Questions: 65-86. Oxford: Oxford University Press.

SUGUNASIRI, SUWANDA. 1999. How to kick multiculturalism in its teeth. Towards a better tomorrow with a critical compassion. Toronto: Village Publishing House.

Zukin, SHARON. 1995. The Cultures of Cities. Cambridge, Massachusetts/Oxford, Gran Bretaña: Blackwell Publishers Inc. 